\title{
Modernist housing estates in European cities of the Western and Eastern Blocs
}

Javier Monclús* and Carmen Díez Medina

School of Engineering and Architecture, University of Zaragoza, Zaragoza, Spain

The aim of this paper is to compare and contrast modernist housing projects in Western and Eastern Blocs built in the period of accelerated urban growth that took place mainly in the $1960 \mathrm{~s}$ and 1970s. The obvious starting point is that cities in the Eastern Bloc were different from Western cities because of the distinct nature of their urban policies, the centrally planned economy, the absence of a free land market, the impact of industrialization on building construction, etc. However, there are many concepts in urban planning and design, as well as urban processes and urban forms, shared by both ideological systems and that can be clearly recognized in housing estates from that period.

This paper offers a comparative perspective of the nature of some of those modern Housing Estates built on both sides of the Iron Curtain such as Grands Ensembles in France, Großsiedlungen in Germany, Polígonos de viviendas in Spain, or Socialist Housing Estates equivalents in Eastern Bloc countries. The goal is to understand how mass housing forms were related to the modernist international urban culture of the Athens Charter and what was the role of urban design in the significant loss of environmental quality appreciable either in the West or in the East in those years of accelerated urban growth almost everywhere in Europe.

Keywords: mass housing estates; socialist housing estates; post-1945 Europe modernism; urban design; urbanity

\section{Introduction}

In his book Urbanistyka krajów socjalistycznych: problemy spoleczne [Urban Planning in Socialist Countries], the influential communist architect and theorist Edmund Goldzamt asserts that urbanism in socialist countries can be seen as a continuation of the tradition of interwar twentieth century European progressive experiences. Goldzamt thought that progressive ideas included in the Athens Charter could be assumed in socialist planned economies. ${ }^{1}$ If we consider these innovative episodes of Soviet Planning, or the avant-garde architecture and urbanism designed in the interwar period by German, Hungarian, Czechoslovakian, or Polish architects, his statement becomes convincing. In fact, after the Second World War, when the decision to give an answer to the growing demand for housing was made, those modernist principles were applied, with some variants, in the housing estates of Eastern European cities as well as in the Western cities. Of course, there were obvious differences - as the terminology itself reflects $^{2}$ - but we can also recognize many common characteristics in urban forms on both sides of the Iron Curtain. Among them, a significant loss of environmental quality in housing estates since the beginning of the 1960s, when the proliferation and a spectacular increase of the size of the estates took place. ${ }^{3}$

*Corresponding author. Email: jmonclus@unizar.es 
Housing estates, particularly modernist housing projects, have been the subject of extensive literature in urban and planning historiography. Although many local studies have been carried out - especially monographs on cities and historical analysis of housing estates - there are very few comparative approaches related to historical and present day debates. ${ }^{4}$ In taking this approach it is necessary to consider how some recognized authors, such as Edmund Goldzamt, understood modern urbanism from a 'socialist' perspective, in front of other architects and planners from the West; or the way Eastern housing estates were designed in this critical time period in comparison with the Western ones.

This paper sets out some fundamental questions about the nature of changing perceptions, eyeopeners, eureka moments, and paradigm shifts in reference models. At the same time, it explores the practical implications of modernist ideals about this complex reality full of paradoxes and ambiguities. Then, it addresses some examples of Western and Eastern European housing estates that were built according to these progressive and functionalist ideas, keeping in mind that often the building process transformed the results in the 'vulgata' of the modernist ideals. ${ }^{5}$ We have tried to consider several cultural and national urban and planning traditions, focusing on some paradigmatic examples of housing estates located in different and complex cities. ${ }^{6}$ Our approach is morphological and emphasizes not a way of building but an 'urban and landscape form', with an open perspective consistent with studies from urban historians, geographers, and architects, and applying an eclectic methodology (secondary sources, mapping, and direct observation of urban forms). ${ }^{7}$ In keeping with Rem Koolhaas' query at the Venice Biennale (Absorbing Modernity 2014), it is about understanding how different 'urban design cultures' have responded to the 'forces of modernism' in the twentieth century. ${ }^{8}$ In view of distinct urban processes in Western and Eastern European cities, can we say that these showed simply different stages of a common process of European urban modernization? How did modernist ideals change in different political and socio-economic systems? How wide was the gap between expectation and realization of 'modern urban utopias' in both Western and Eastern cities in this particular period? What went wrong? How often did it go wrong?

Many of the historiographic interpretations are based on a 'different stages' hypothesis, meaning early modernization in some countries was followed by later modernization in others (especially in Eastern countries). Looking with a comparative perspective, it does not seem so obvious. Rather than different stages between Western (advanced) and Eastern (backward) countries, it would appear that a common change in the conditions of urban growth happened almost at the same time, during the 1960s and 1970s when housing estates spread in all European cities with their size increasing spectacularly. The issue here is the contribution and responsibility of the 'modern planning and urban design culture' with its different versions in East and West, especially regarding modern housing estates in those decades. It is not so clear that all of these modern housing estates were so 'well planned at the time' as some official reports from the European Commission assert. ${ }^{9}$ Obviously, not all of them were so well designed, but neither urban design should bear the whole responsibility.

This paper does not explicitly consider important issues such as market situation, technical know-how, behaviour of people, planning law, influence of politics, etc., instead, what it tries to identify is the strengths and weaknesses of modern urban planning and design culture models, especially when radical urbanism was applied in the period of accelerated urban growth. Reviewing this episode of modernist architectural and urban history the paper aims to offer greater nuance and a comparative view, including some examples from Southern Europe which are usually neglected. 


\section{Modernist ideals, modernist mass housing, 1920s-1970s: paradoxes and contradictions}

At the International Congresses of Modern Architecture 2 (CIAM 2 (Frankfurt, 1929)) and CIAM 3 (Brussels, 1930) Walter Gropius demonstrated with scientific precision the problems old housing models (Mietkasernen in Berlin) entailed and he championed the high-rise linear block as an alternative (Figure 1). Urban blocks with conventional streets largely went out of fashion. ${ }^{10}$ Instead, highway arteries, isolated high-rise buildings, and green spaces became dominant in modernist layouts. This was an important paradigm shift related to the prestige of Taylorism and Fordism (among other factors) that implied new ways of ordering urban spaces. ${ }^{11}$ From the 1920 s onward, modernist urbanism was based on radical innovations in housing and urban forms, ${ }^{12}$ but nowhere this was so clearly expressed through explicit urban forms as in Gropius radical proposals. ${ }^{13}$

Under this planning and urban design perspective, we can assume that, after the Second World War, in spite of different cultural traditions and socio-political situations (including some exceptions with interesting architecture and urban layouts), housing estates of the 1960s and 1970s radicalized the functionalism and pragmatism of the Modern Movement and the Athens Charter (CIAM 4, 1933, published in 1943). Of course, this was a complex, contradictory, and paradoxical process, since the large housing estates began to be built according to the CIAM principles at the same time that they started to be rejected by different urban theorists and practitioners.

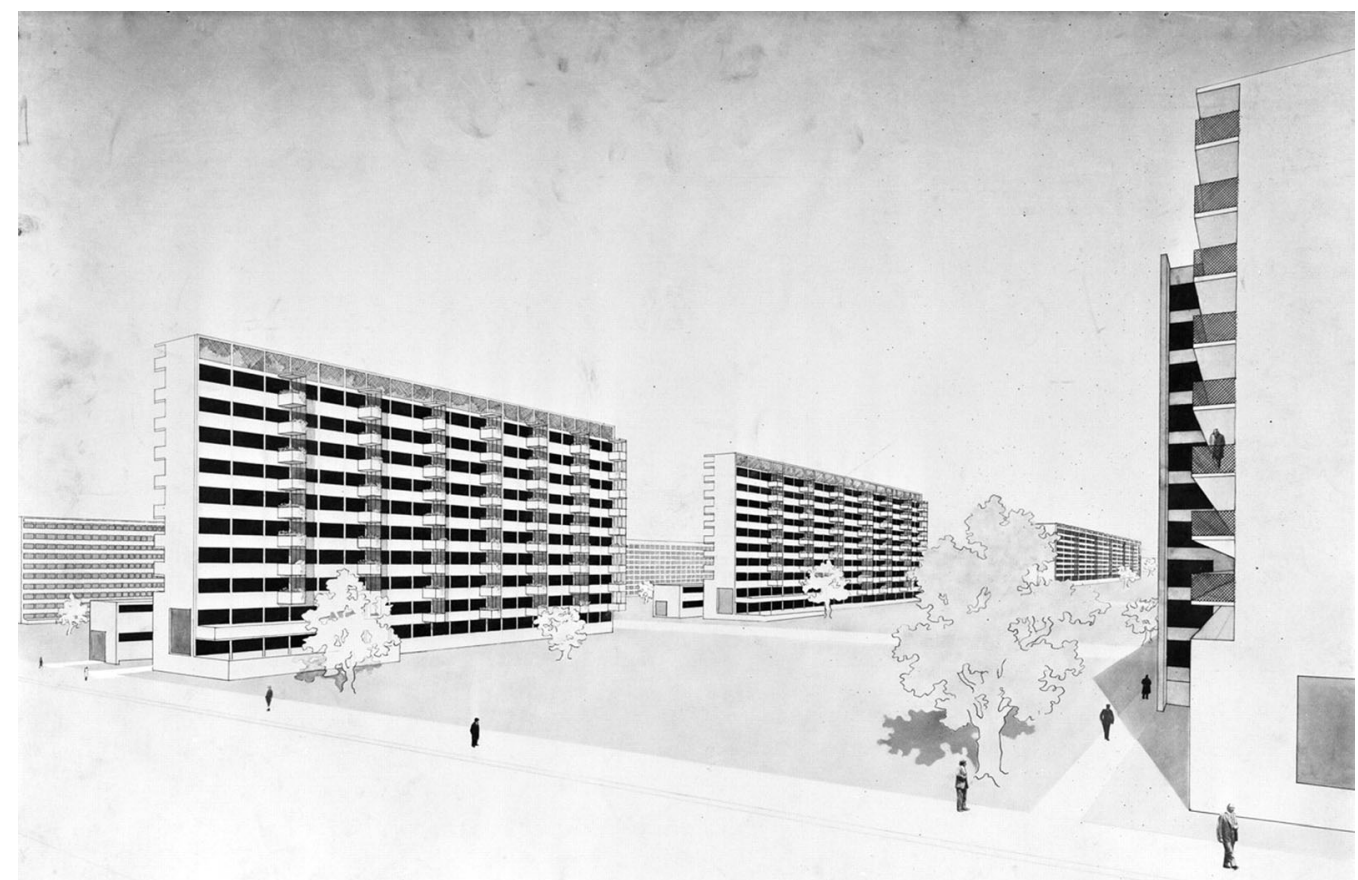

Figure 1. W. Gropius, High-rise housing, CIAM 4, Bruxels, 1930. 'Houses, Walk-ups or High-rise Apartment Blocks?' Modernist high-rise linear block as an alternative to the old housing models and traditional urban layouts (Source: CIAM, Rationelle Bebauungsweisen, 'Flach-, Mittel - oder Hochbau?', 1931). 
If we could identify one 'zero hour' as a starting point for the revision of the radical urban avant-garde, we should go back to 1950/1951. In 1950, 16 Grundsätze des Städtebaus (Sixteen Principles of Urban Planning) were passed in East Berlin. ${ }^{14}$ Almost at the same time, in 1951, the CIAM 8 The Heart of the City took place. Both texts show that paradoxically, while the Athens Charter principles were starting to spread everywhere in the $1950 \mathrm{~s}$, a parallel revision process was already beginning to gain momentum with the reconsideration of traditional urban forms. The Sixteen Principles of Urban Planning, as a counterpoint to the Athens Charter, combined the ideas of the modern urbanism of the 1930s with Stalin-era, Soviet concepts. ${ }^{15}$ In this sense, it is interesting to note that 'Stalin's attempt to squash the re-emerging modernism, supplanting its legacies with a new aesthetic that extolled the virtues of a socialist society, ${ }^{16}$ could be related not only to 'socialist realism' but also to the revisionist debate, present at the CIAM 8, on the importance of the cultural dimension in cities; another way of questioning CIAM functionalist urbanism.

To sum up, the first common paradigm shift to modernity took place from 1933 to 1943, but it was the rigidity of the modernist principles that quickly led to a second shift after the Second World War. It was supported by a 'modernist second generation', more sensitive to the values of old cities, urban cores, and 'hearts', to the contrast between the quality of traditional urban spaces and the poverty of modernist ones, to the lack of urbanity in new developments, etc. ${ }^{17}$ Of course this did not happen at once in all places and furthermore the urban planning traditions differed among countries and cities, as the recent intense historiographical debate, still open, shows. ${ }^{18}$

Two texts, published in the early 1960s in West and East Berlin, demonstrate how fast utopian views turned into critical and negative voices. In West Berlin, the publishing of The Murdered City in 1964 by Wolf Jobst Siedler with photographs by Elisabeth Niggemeyer was an important landmark. One year before, The City of Tomorrow, based on the collected letters between Brigitte Reimann and Hermann Henselmann, had already afforded other critical views coming from the eastern side. However, criticism spread from everywhere: the texts by J. Jacobs (1961), G. Cullen (1961), C. Alexander (1964), A. Mitscherlich (1965), or A. Rossi (1984) illustrate perfectly the growing criticism and rejection of some aspects of modernist urbanism, especially the large-scale housing projects built in the 1960 s either in Western or Eastern cities. ${ }^{19}$ With some variants, most of the criticism summarizes the problems and weakness as follows: lack of urban life because of the single functional zoning; neglect of the human scale in large-scale estates and buildings; difficulties of isolated and fragmentary urban groups integrating into the city, etc.

Anyway, neither the impact of criticism nor the view of the 'modernist second generation' was particularly significant since the increasing size of housing estates and the rapidity of the building process became the norm from the end of the 1950s onwards. Since that moment, the shift from the huge expectations that modern urbanism had awakened to the questioning and eventual verification of the failure was brief and conclusive.

\section{Modernist housing estates in Western and Eastern Blocs: 'Modern urban culture mistake' or 'low-quality urban design'?}

\section{Western Bloc}

The building and proliferation of large housing estates was exceptional all over Europe during the 1960s and 1970s. This was firstly due to the critical shortage of houses and the willingness to 
solve this problem rapidly; and secondly, because standardization and prefabrication afforded the possibility of building quickly, consequently, both planners and governments found it convenient to postulate the CIAM theories. The problem arose when these principles were quickly adopted in the context of accelerated urban growth. Of course modern architecture and urban planning resulted in the indisputable improvement of life quality and habitability, but they also brought with them noteworthy weaknesses resulting from the excesses of radical urban innovation and of the limited attention paid to urban and architectural design. ${ }^{20}$ Rather than talking about a 'mistake' in the statements of the modern urban culture we should consider the vulgarization of the CIAM tenets in the 1960s and the generalized low environmental quality in urban design and architecture. ${ }^{21}$ This happened both in the West and in the East, as an amazing unifying force which 'defied the dichotomy of the Cold War', 22 as the ensuing examples evidence.

As in other Western European countries, in the UK the modernist tradition was so deep that 'the modern movement finally became the new orthodoxy of the $1960 \mathrm{~s}$ ' ${ }^{23}$ The intense debate and battles on housing models gave rise to important examples, such as the Churchill Gardens in Pimlico (1946-1962), a true laboratory of high quality urban forms, or the Roehampton flats in West London (Alton East and Alton West, 1953), an expression of the 'Corbusian dream' in the UK. ${ }^{24}$ Park Hill Housing Project in Sheffield (1954-1961), 'one of the most celebrated public housing schemes of the post-war period' and one of the first paradigmatic episodes to show the gap between expectations and realization 'enjoyed qualified critical approval'. ${ }^{25}$ Shortly after its completion the critic Reyner Banham did not stint his praises:

Park Hill seems to represent one of those rare occasions when the intention to create a certain kind of architecture happens to encounter a programme and a site that can hardly be dealt with in any other way, and the result has the clarity that only arises when - as in the Villa Rotonda - aesthetic programme and functional opportunity meet and are instantly fused. ${ }^{26}$

However, since the end of the 1950s 'Modernism became indelibly associated with social housing and with being the dwellings of those who had no choice'. ${ }^{27}$ So what went wrong? The decline of Park Hill came soon, largely due to the devastation of the steel industry and also to council housing policies that contributed to damaging the original ideal of equality: Park Hill became the ghetto of a suppressed underclass, a sink estate. But the urban and architectural design also contributed to the decline of the estate: public spaces belonging to nobody soon turned into neglected and desolated corridors, and 'radical modernist concepts' led to complete standardization of architectural solutions, which was not the best way to facilitate its appropriation by the new inhabitants ${ }^{28}$ (Figure 2).

The Bijlmermeer neighbourhood (1966-1972) in Amsterdam was also a paradigm of modern urban planning. It was presented as an advanced suburb in the motorized age, an achievement by the most radical functionalists. ${ }^{29}$ Curiously, even if the authors were disciples of the great architects of the glorious former generation (van Eesteren, Bakema), we can find a strong contrast between the radical and simplified forms of this large-scale estate and the carefully designed modernist Amsterdam Western extension. ${ }^{30}$ Only 10 years after Bijlmermeer had finished being built, this modern icon turned into a recognized mistake, as it happened in Park Hill. $^{31}$ So, what went wrong this time? The construction of Bijlmermeer coincided with large migratory flows as a result of the independence of the former Dutch colony of Surinam in 1975, resulting in many immigrants being housed there. But this could not be the only 


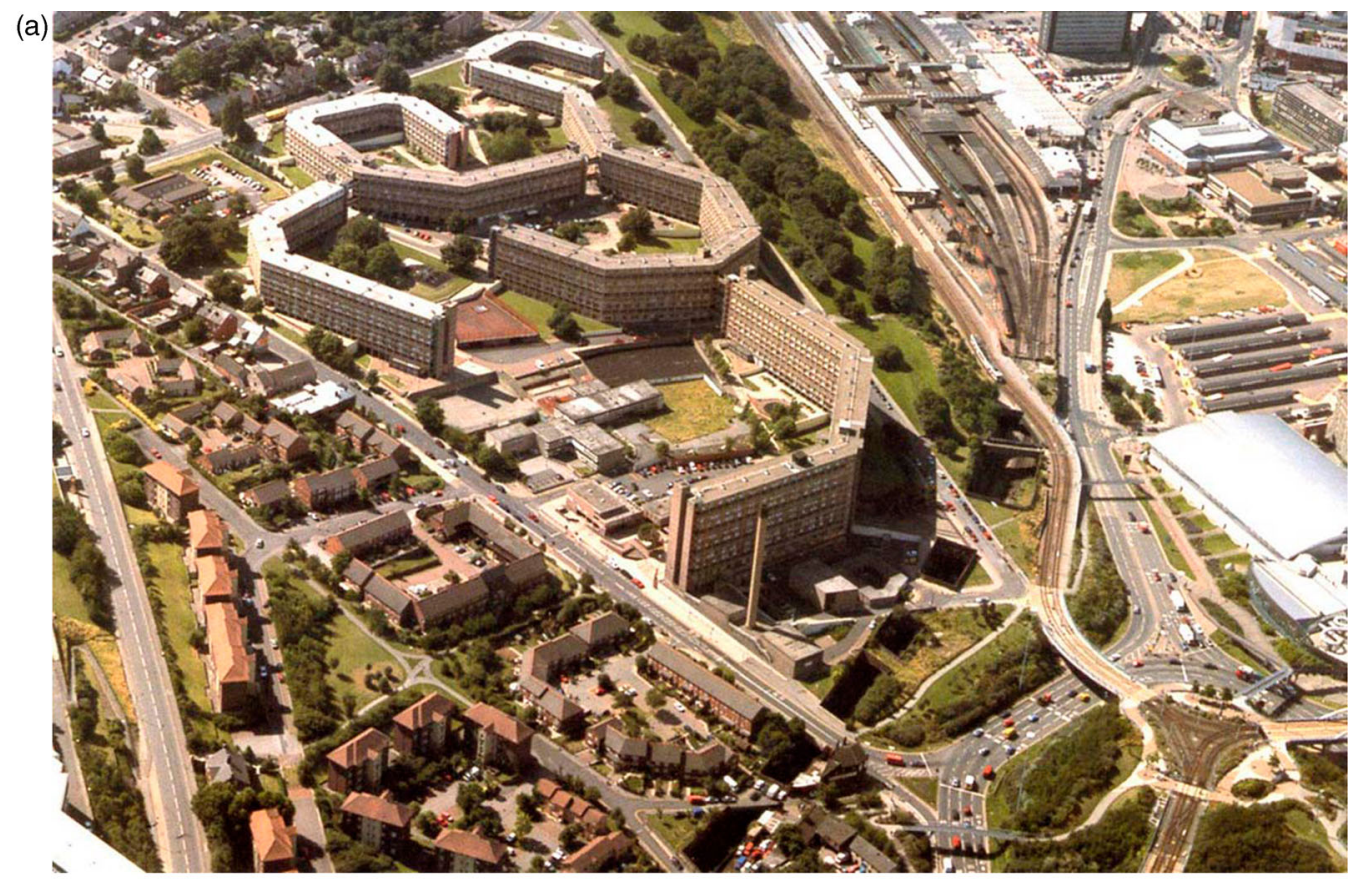

(b)

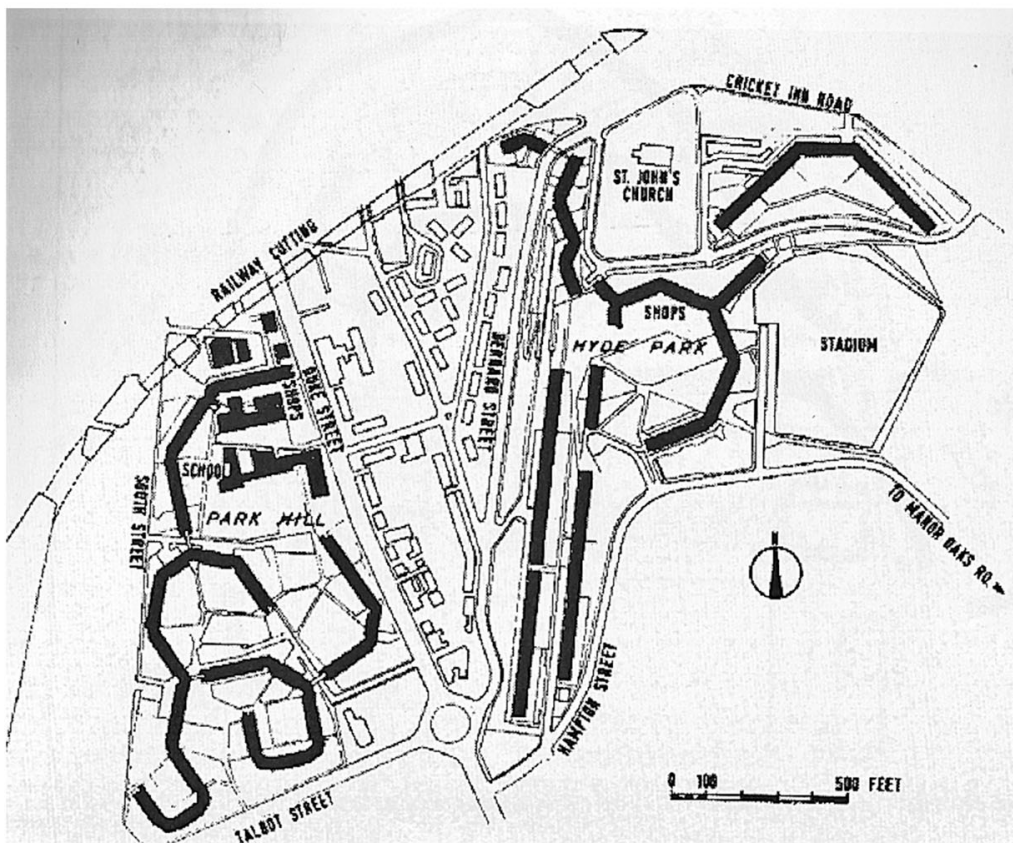

Figure 2. (a and b) Park Hill, Sheffield, 1954-1961, 1000 units in blocks ranging from 4 to 13 storeys (24 ha). Radical modernist concepts led to complete standardization of architectural solutions, but the middle size scale allows an easier control of the public spaces and facilitates the development of regeneration programmes (Source: Pérez Igualada, Javier. Manzanas, bloques y casas. Formas construidas y formas de suelo en la ciudad contemporánea. Valencia: UPV, 2005). 
explanation for the failure. Besides these social problems, an excessive ambition led to believe that a large-scale urban project could be conceived and design just as a large-scale architectural one. Bijlmermeer demonstrates how projects become more complex when the scale increases and concepts radicalize. ${ }^{32}$ As Rem Koolhaas says, 'the Bijlmer represents a particular architectural doctrine realized in retrospect ... So near and yet so far ... Pre-war CIAM urbanism realized in the late sixties'. ${ }^{33}$ Here we see the paradox of the application of pre-war CIAM tenets in the 1960s, in a moment where they were already being rejected. Again, the urban and architecture design was not the only thing responsible for the problems, but it showed the limits of those megastructures (Figure 3).

Looking now to Sarcelles (1955-1970), on the outskirts of Paris, we find one of the most significant French cases - a sort of archetype of grand ensemble ${ }^{34}$ representing an obvious example of the radical application of modernist concepts and of the absolute standardization of architectural solutions. Its monolithic composition in horizontal residential slabs was organized in a rigid grid in strict compliance with rationalist CIAM tenets, with much less attention to the urban forms that had been paid to earlier post-war projects, such as Le Havre or Montrouge (1955-1958). The existing literature is strongly critical (as with previous examples) due in part to the prevalent use of prefabrication that led to a general rejection in the 1960 s. $^{35}$ Despite considerable experimentation in some of the grands ensembles (such as in Toulouse-le-Mirail, a sort of 'megastructure' like Park Hill or Bijlmermeer) the results were poor: resulting in morphological monotony, hard architecture, and lack of facilities, commercial areas, and activities. The fact that Sarcelles has given its name to the mal des grands ensembles, la Sarcellite or sarcellitis, ${ }^{36}$ is symptomatic enough (Figure 4).

Among all the different European urban cultures Germany stands out since the Weimar Republic because of its deep modernist tradition linked to social housing programmes. Reference architects such as W. Gropius, H. Meyer, B. Taut, and E. May developed a systematic reflexion about mass housing in the interwar period, and German cities became a true laboratory for large-scale housing estates. Gropius himself was the author (with Wils Ebert and his American office The Architects Collaborative (TAC) of one of the most paradigmatic Großsiedlungen in Berlin: Gropiusstadt (1962-1975)). This extraordinary example gives interesting clues for understanding some strengths and weaknesses of these large-scale housing estates in contrast to earlier experiences built up until the 1950s. Was this large-scale housing estate so 'well planned at the time?' Despite the typological diversity, radical modern tenets (too fluid, open with no well-defined spaces, and no clear hierarchy) dominated. The image of the modernist development was discredited by being linked to drugs and social problems, especially after the success of a book by a teenager who lived at this large-scale housing estate. Again, urban forms were credited as being responsible for these problems. Despite this rather unfair association, recent analysis found many weaknesses (as well as strengths) in the original project and the layout of the estate. ${ }^{37}$ As it happens, the Gropiusstadt, and the Märkisches Viertel $(1963-1974)^{38}$ in West Berlin, could be seen as 'textbook example[s] for the Großsiedlungen experience'. 39 Both examples were defined by tall blocks and huge open spaces according to similar urban principles, not dissimilar in concept to the grands ensembles or their Dutch and UK equivalents (Figure 5).

Less attention has generally been paid to the experience of housing estates in Southern Europe. In Italy, modernist tradition had its own development after the Second World War and became also the new orthodoxy in the 1960 s urbanism. ${ }^{40}$ As with other Southern European 
(a)

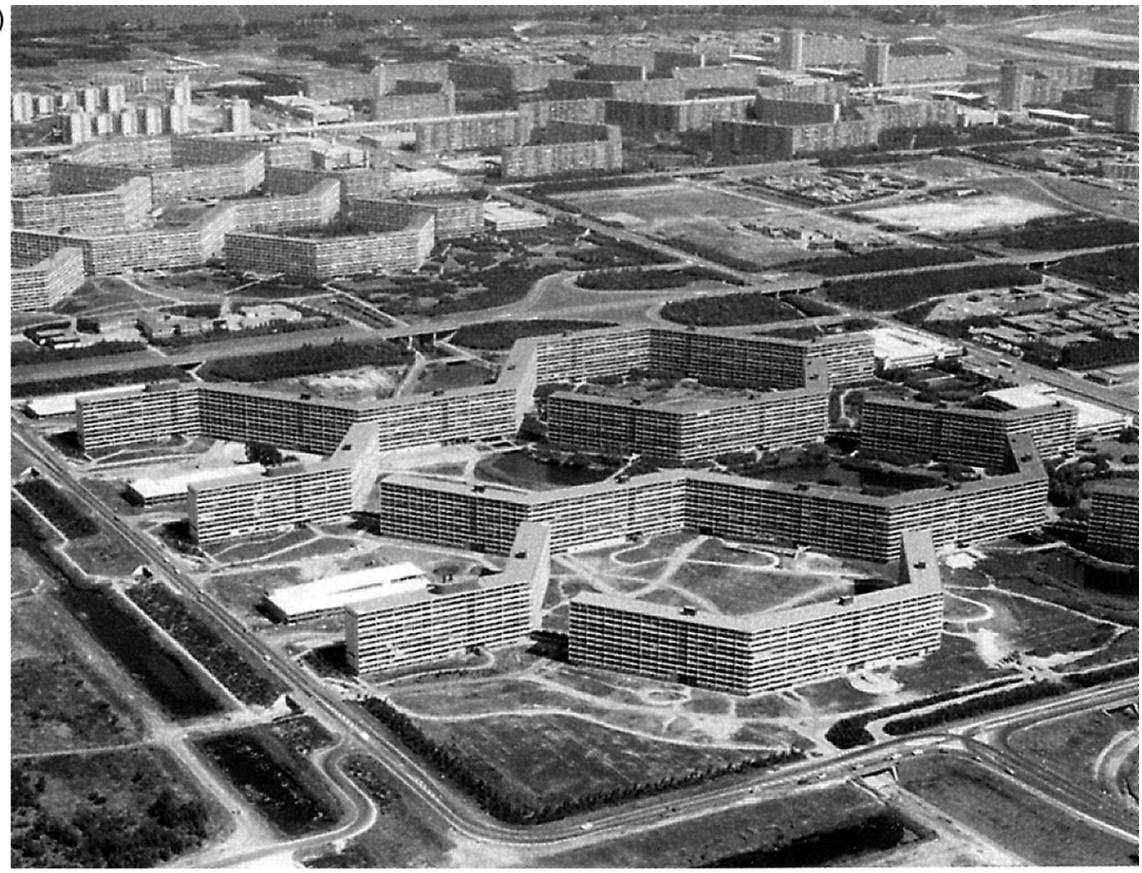

(b)

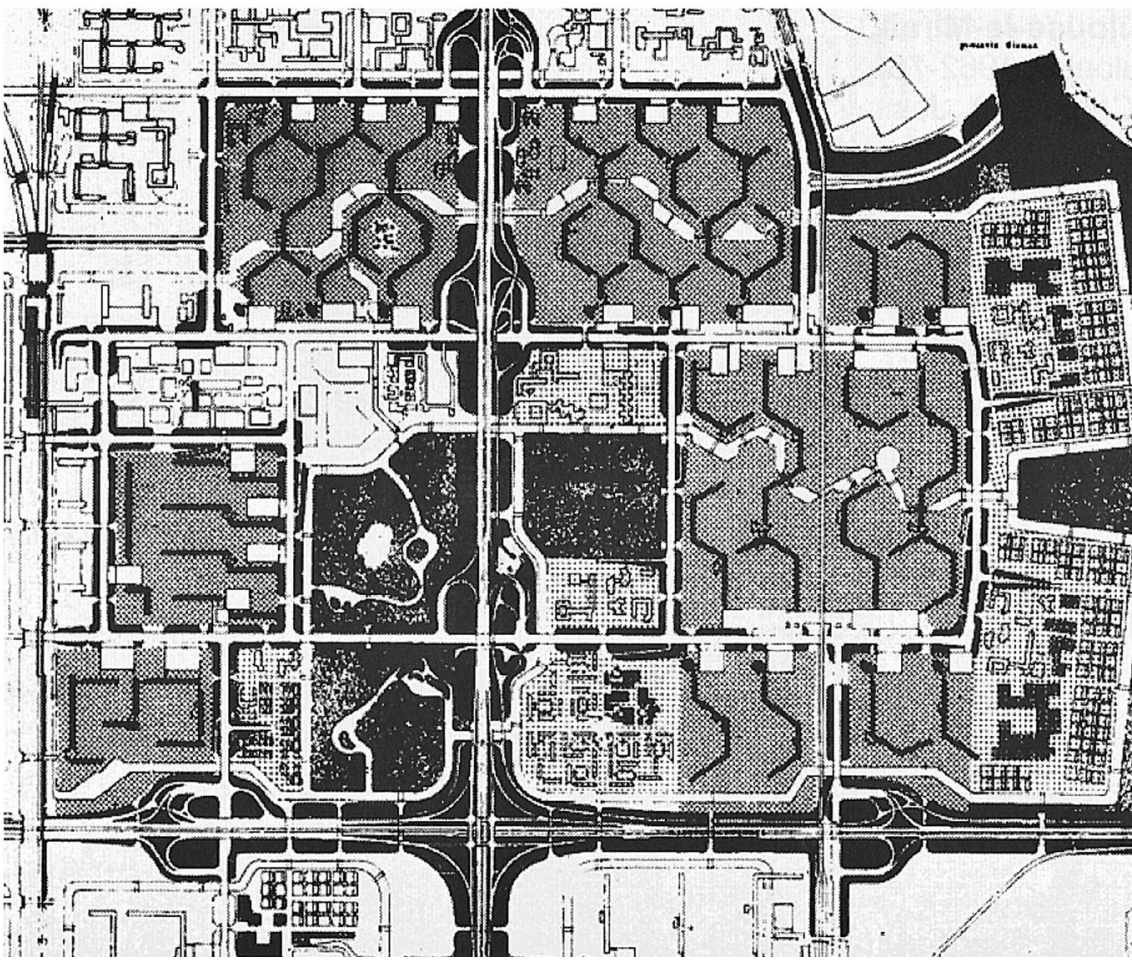

Figure 3. (a and b) Biljmermeer, Amsterdam, 1966-1972, 13,800 units in 10-storey blocks. An advanced suburb in the motorized age, an achievement for the most radical functionalist. Although the urban and architecture design was not solely responsible for the problems, it showed the limits of megastructures (Source: Pérez Igualada, Javier. Manzanas, bloques y casas. Formas construidas y formas de suelo en la ciudad contemporánea. Valencia: UPV, 2005). 
(a)

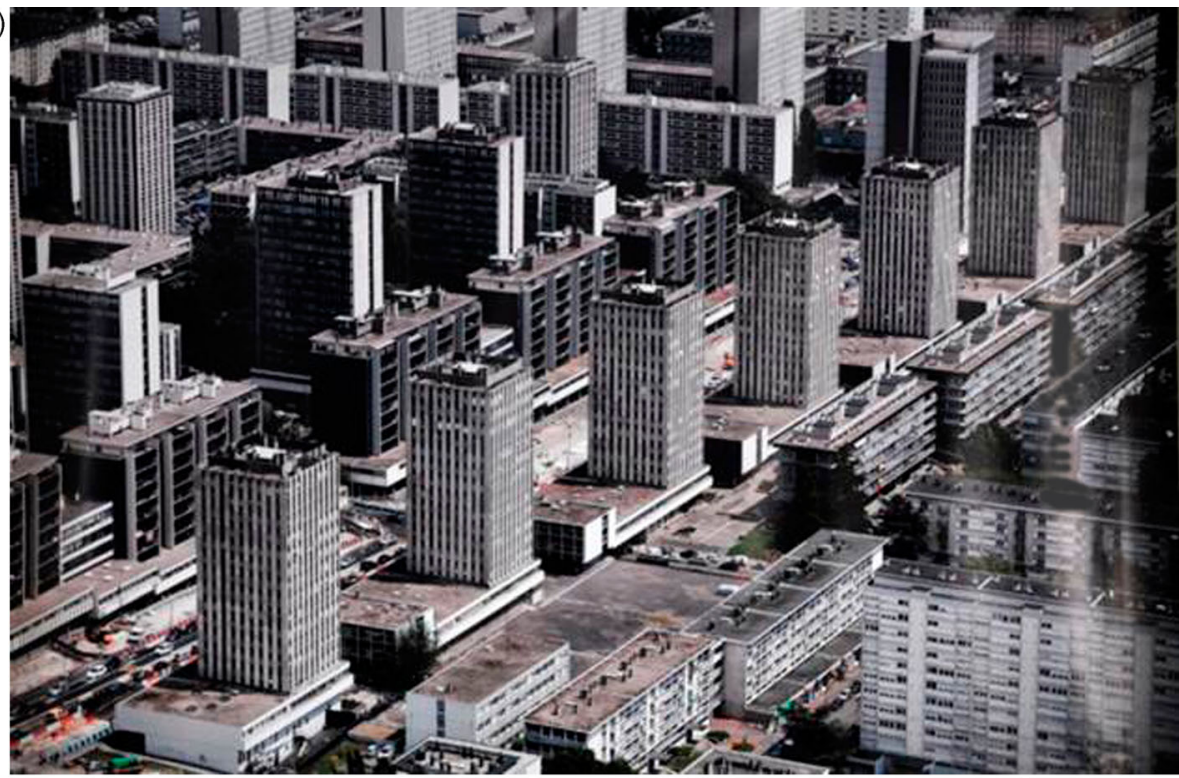

(b)

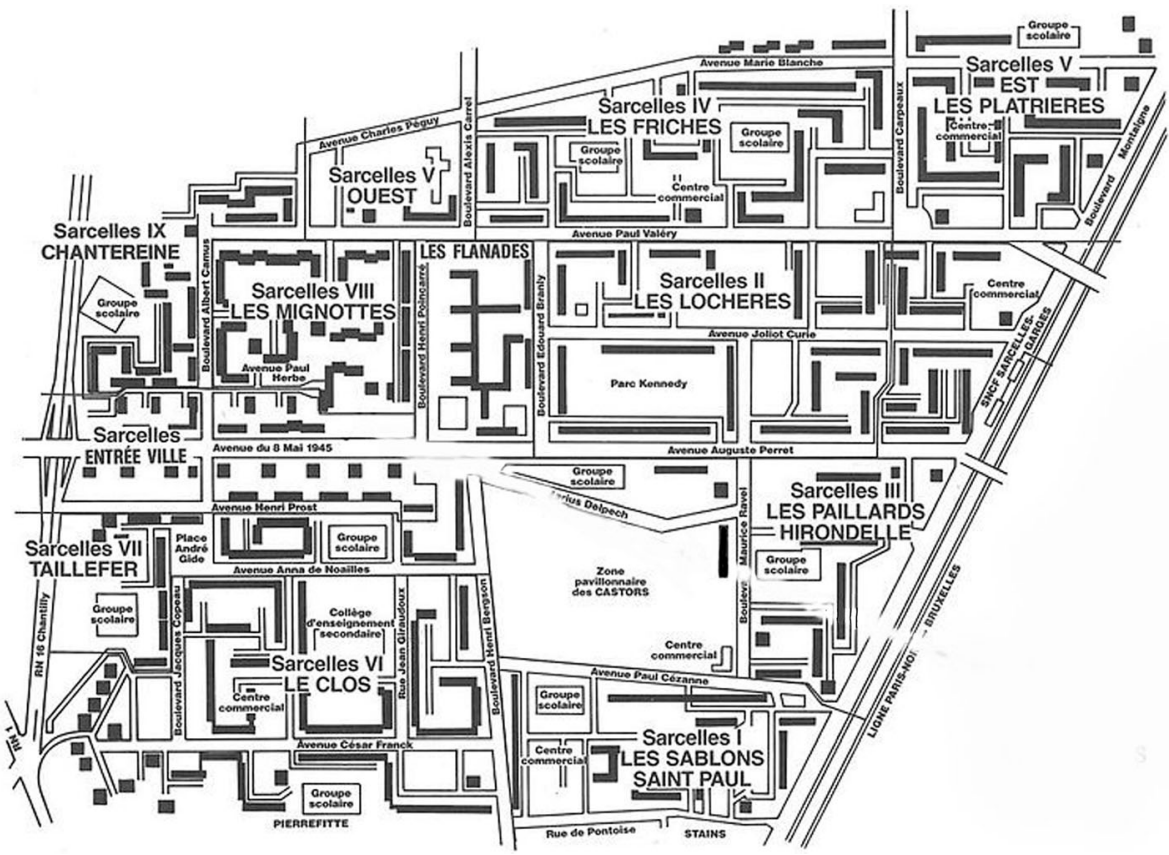

Figure 4. (a and b) Sarcelles, Paris, 1955-1970, 12,400 dwellings in bocks ranging from 3 to 14 storeys ha?. The particular episode of the grand ensembles can be seen as one of the most emblematic products of public urbanism. The high number of these estates is a further challenge added to the excessive standardization of architectural solutions and to their large scale (Source: Wikimedia Commons). 
cities, the economic development of the 1960s led to an explosion of self-built neighbourhoods, borgate, and mass housing estates gained relevance, producing interesting examples. ${ }^{41}$ The case of Quarto Cagnino in Milan (1964-1973) $)^{42}$ contrasts strongly with the experiences of the 1950s such as QT8 in Milan (1953), or Tuscolano in Rome (1950-1952). This estate had several problems from the beginning and, as it happened in other case studies already mentioned, they were not only of urban or architectural nature: for instance, the legal framework limited the development of public housing estates to the availability of economic plots, that sometimes, as in Paris, were marginal appendix to the city. ${ }^{43}$ 'The 120 thousand public housing dwellings planned in 1961 turned into a galaxy of settlements localized in whichever areas were available to construct on, that is to say the most distant suburbs'. ${ }^{44}$ Besides that, the plan's economic limitations hindered the complete development of the original project, which provided carefully designed inbetween spaces and different housing typologies, paying special attention to the connection of common spaces with the private sphere. These changes, as in other previous cases, resulted in the poverty of public space and in the low urban quality of the estate (Figure 6).

Spain shares with Italy a common urban design culture related to a tradition of 'urbanism' that differs conceptually from the Anglo-Saxon 'town planning': 45

In that structure, as a valuable intermediate step between the city-municipality and the familyhouse, the 'barrio-polígono' has been introduced; the 'neigbourhood unit' of British urban planners, the 'Siedlungen' of the Germans, or the 'grands ensembles' of the French were baptized 'polígonos' (housing estates) in Spain, although with the ambiguity that the use of a definition implies, resorting only to the assistance of geometry. ${ }^{46}$

Besides the important experiences of the post-war poblados dirigidos and poblados de absorción in Madrid, in other Spanish cities there were also many other good examples of modern housing estates built in the 1950s and 1960s, such as the ones 'listed' in heritage institutions, such as the International Working Party for Documentation and Conservation of Buildings, Sites and Neighbourhoods of the Modern Movement (DOCOMOMO) Ibérico. ${ }^{47}$ Then, as in other Western cities and countries, this earlier 'well planned' poligonos de viviendas of the 1950 s contrast with 'an avalanche of low-quality architectural projects' that characterized a large part of 1960s and 1970s modern Spanish peripheries. ${ }^{48}$

Gran San Blas in Madrid (1958-1963), ${ }^{49}$ the largest housing estate of the period in Spain, was based on the modernist concept of a district divided into neighbourhood units. In this case, the different solutions applied to the various units reveal that there was no unified approach and that the attitudes towards the Athens Charter tenets varied. This circumstance helped to avoid the monotony of other estates. Curiously, the unit designed more in accordance with the CIAM tenets maintains a certain urban quality, since the size of open spaces and buildings is somewhat reduced and proportionate; strong evidence of the importance of the scale. In Gran San Blas the main problem lies in non-built areas and neglected open spaces. That was in part the result of the definition of residual spaces between the different units, since volumetric options had the main role in the design proposal. There is another important factor to take into account: the obsolescence of the construction and also of the dwelling types, initially thought to house a population coming from shanty towns (Figure 7). ${ }^{50}$

Also in Barcelona the poverty and inflexibility of most of the urban layouts of the poligonos de vivienda reflected a rigid interpretation of modern architectural culture tenets. Of course, the wish of private and public developers to simplify projects to obtain the best conditions for strict 
(a)

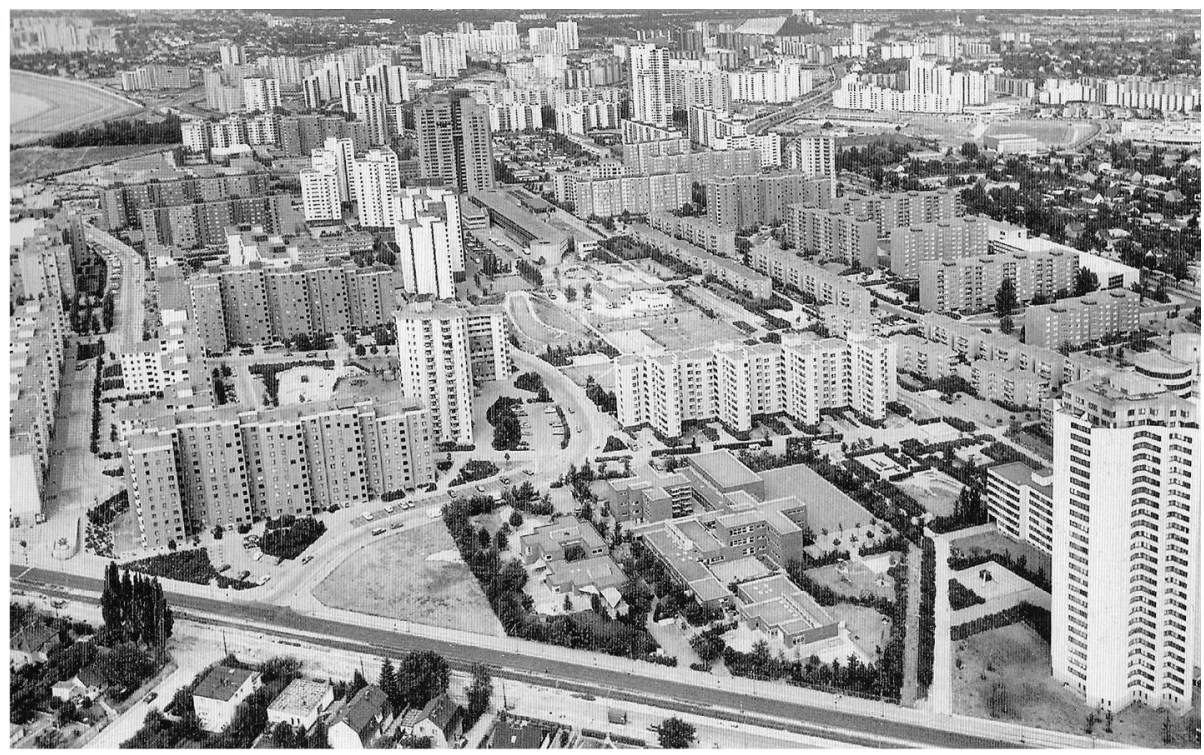

(b)

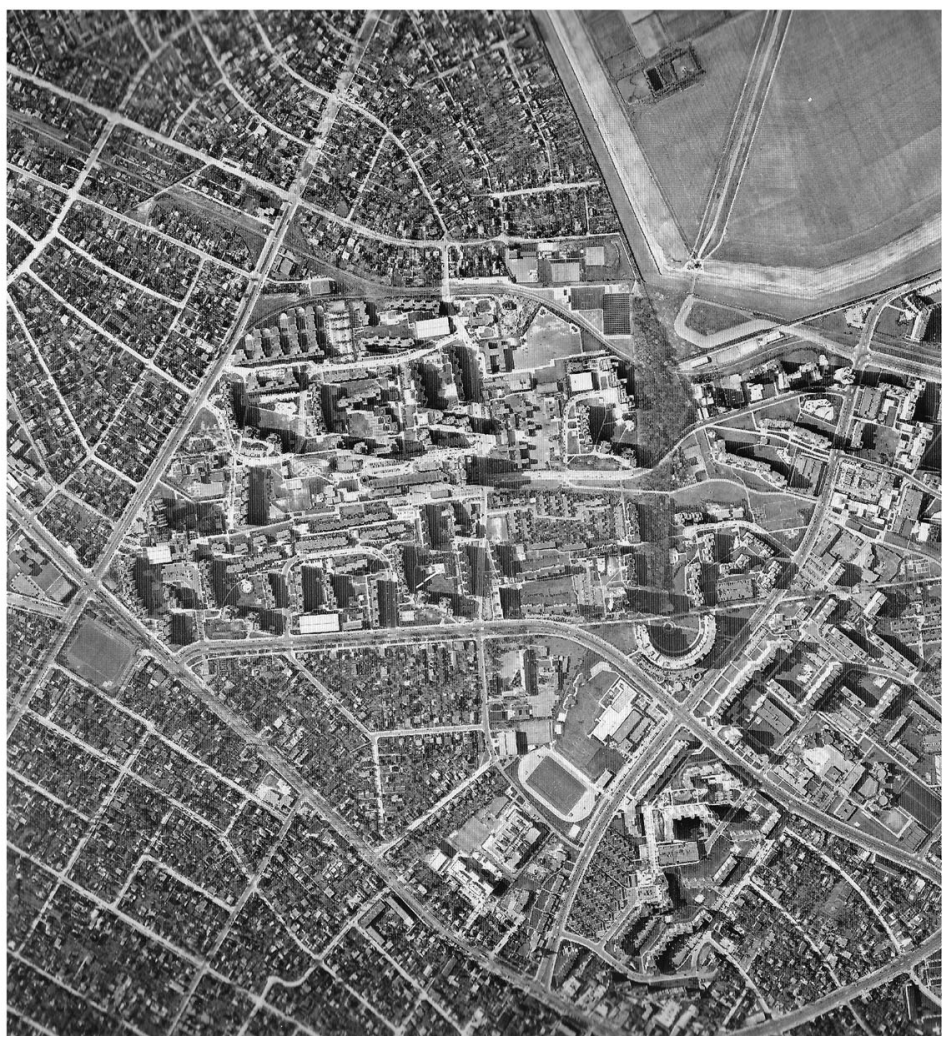

Figure 5. (a and b) Gropiusstadt, Berlin, 1962-1977. Views from 1976 and 1979. Its concept does not differ essentially from the grands ensembles or their Dutch and UK equivalents (Source: Bielka, F., and C. Beck. (Hg.). Heimat Großsiedlung. 50 Jahre Gropiusstadt Entwicklungsmöglichkeiten für die Zukunft. Berlin: Nikolai Verlag, 2012). 
(a)

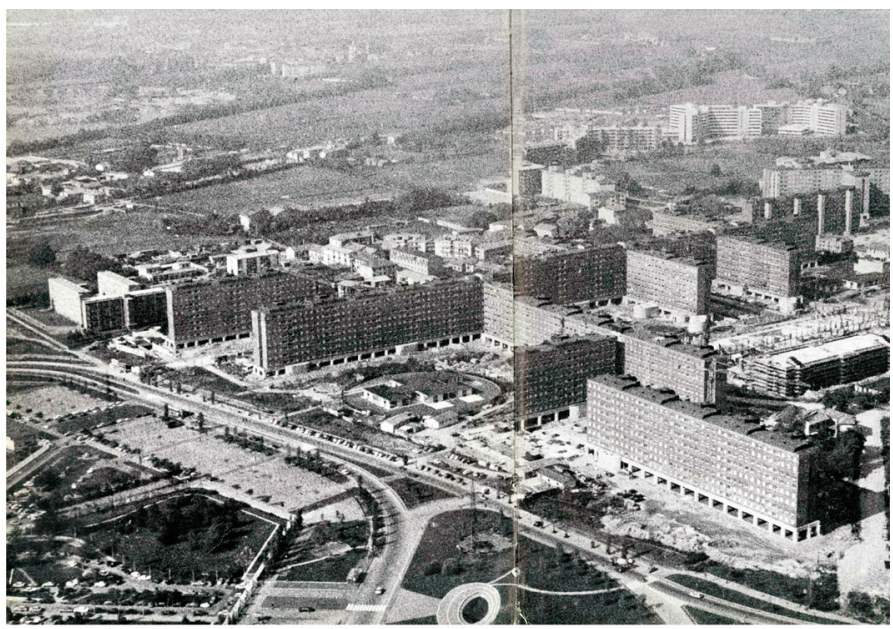

(b)

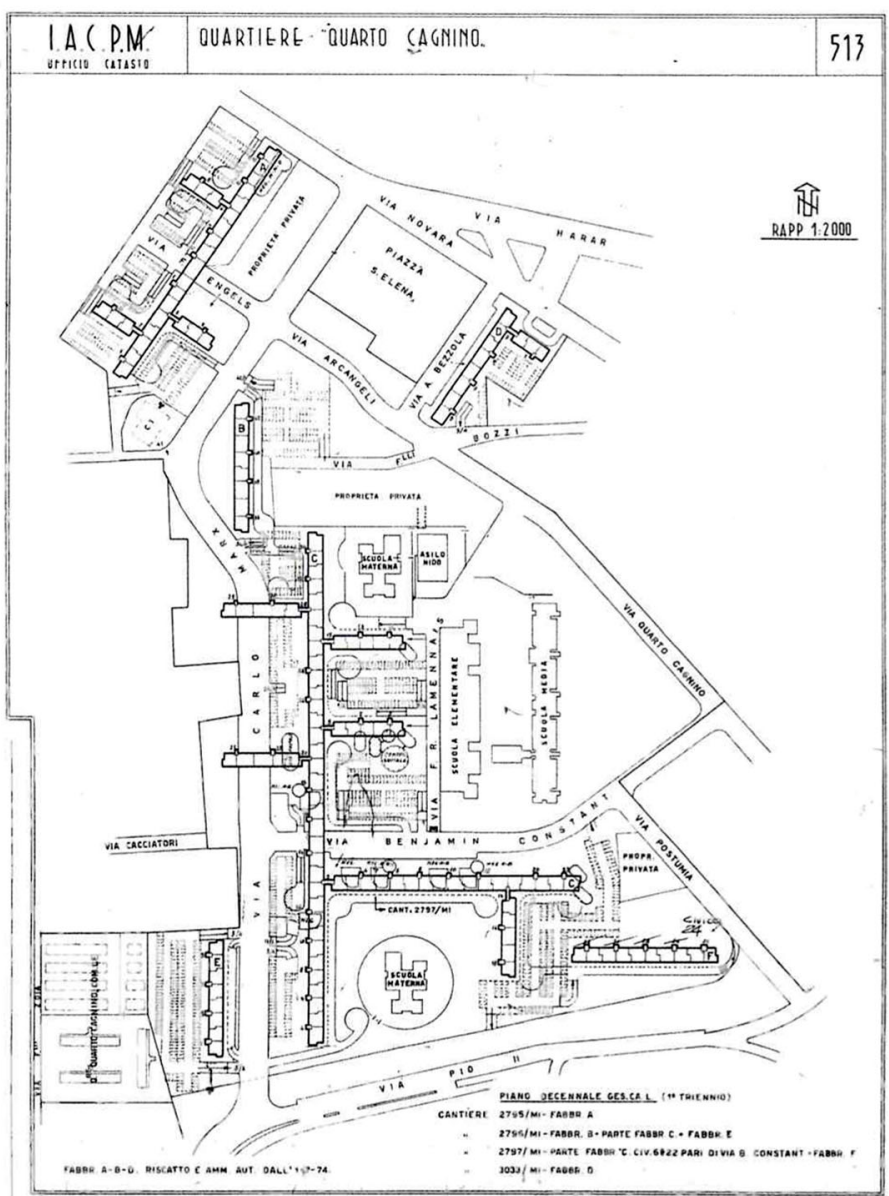

Figure 6. (a and b) Quarto Cagnino, Milan, 1964-1973, 1100 units in eight storey blocks (23.6 ha). An uncommon example of a coordinated programme as alternative to the self-sufficient neighbourhood model Its location in a maroinal annendix of a neripheral area make difficult the inteoration into the 
housing production can easily be recognized. This was a generalized situation that did not prevent certain experimentation with some interesting results. That is the case of the so-called Besós Southwest estate (1959-1961), ${ }^{51}$ the largest housing estate in Barcelona built in the North-east area of the city. It may serve as an example of a prototypical poligono de vivienda even if it is, at the same time, exemplary: 'Different lengths and heights, separation and thickness, with considerably varied architectural and housing typologies, show that will of innovation which results in a quality architectural project which contrast with others in the same city and period' (Figure 7).

In Saragossa the polígonos de viviendas Ebro Viejo (1964-1970) and Gran Vía-Romareda $(1961-1975)^{53}$ were also designed in accordance with modernist urban principles, even if their application was not so radical and the scale of public spaces was rather domestic. Together with Besós Southwest they are among the best estates of that period in comparison to many others of lesser urban quality. However, problems arose again in some of them: isolation resulting from the design as independent urban fragment, spaces in-between neither well defined nor maintained (no man's land), etc. Furthermore, in Ebro Viejo, the rigidity in the location and design of commercial facilities has become obsolete: most of the little shops, that helped to configure the domestic public spaces, stand abandoned in the interior of the estate. On the other hand, although buildings are well maintained, the lack of some facilities, such as elevators, has led to the loss of the apartment's value and has become one of the most important problems for an aged population (Figure 7). ${ }^{54}$

The analysis of these Spanish examples yet again shows the heterogeneity that can be found both in different project strategies and in the resulting urban forms. There is a wide variety in the integration, in the context of these relatively autonomous units (planned and managed as a whole), in the morphology of the estates, in the design and scale of the in-between spaces, in the way they integrate in the topography, and in the architecture of towers and slabs that contribute to their morphological definition. Yet in all of them, the legacy of the modernist urban principles constitutes the basis of their urban design. Many have a monolithic character, due in part to a scarce typological diversity. Generally speaking, achievements, weaknesses, and difficulties are shared by most of the mentioned estates. Nevertheless, in the Spanish examples there is an important difference with other European countries: in many cases the dwellings have been sold and become private property, so the social decline has not been so obvious as we have seen in Park Hill, Bijlmermeer, or Märkisches Viertel, and the existence of ghettos is not so extreme.

\section{Eastern Bloc}

As in the Western countries, the critical shortage of housing after the Second World War led to an accelerated process of urbanization almost everywhere, obviously with some differences, and the modernist ideals seemed perfectly suited to the new circumstances. Because of this, the arrival to the Soviet Union of avant-garde architects from Western Europe in the 1930s, with their strong idea 'that the modern way of building houses could be best realized by following the production methods of a Ford automobile' can be seen as a sort of selective borrowing of some of the fundamental CIAM tenets. ${ }^{55}$ So, Eastern new estates were based on a version of modernist urban design paradigms, as happened with the 'organic urbanism' and neighbourhood unit concepts, which were the basis of the new urban planning. It is therefore not surprising that the 1935 Moscow Plan, with obvious connections to Western counterparts, had also already 
(a)

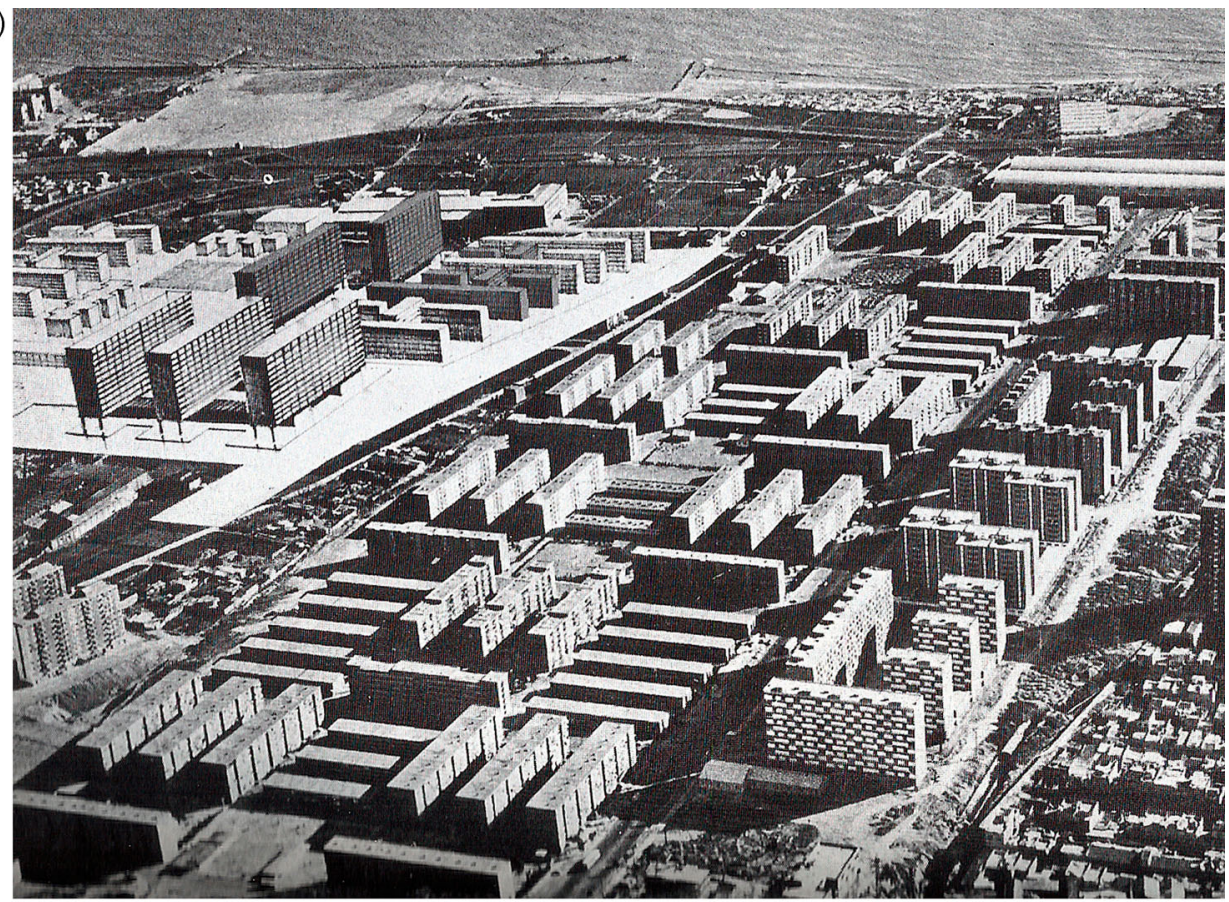

(b)

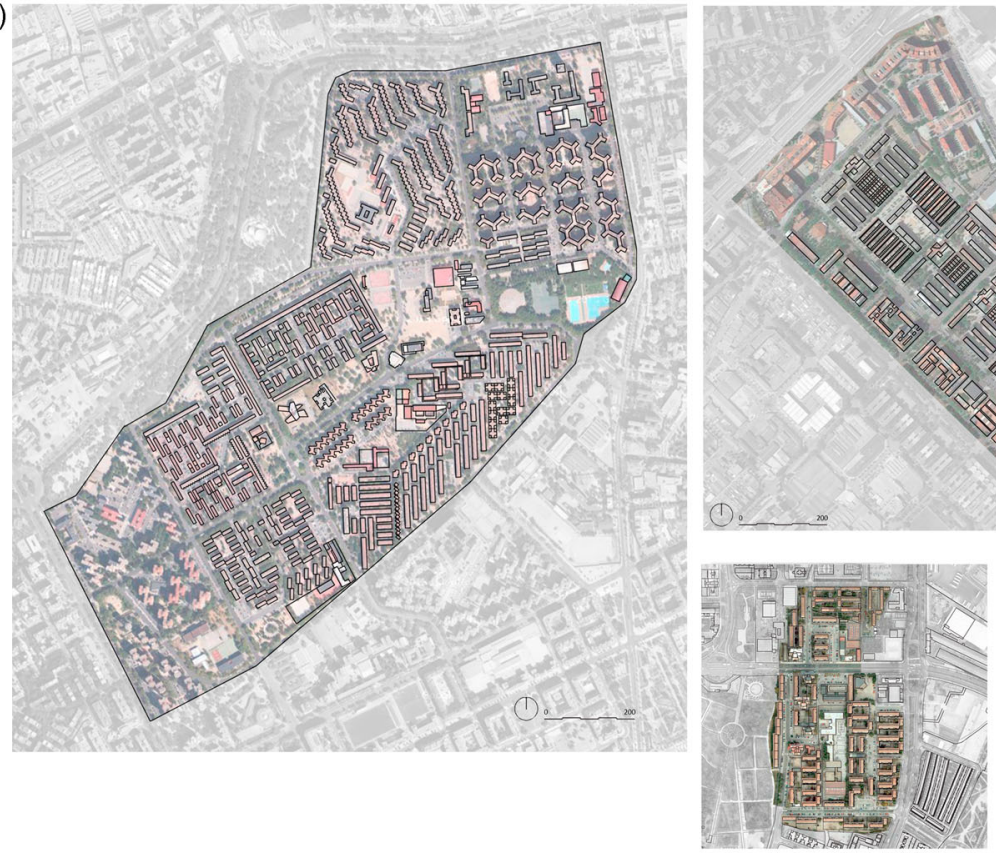

Figure 7. (a) Sudoeste del Besós, Barcelona, 1959-1961. This largest housing estate in Barcelona built in the North-east area of the city, may serve as an example of a prototypical and at the same time expemplary poligono de vivienda (Source: Ferrer, Amador. 'The Undeserved Credit of the Housing Estate.' In Contem- 
established these new urban tenets for other soviet cities. ${ }^{56}$ Sharing the spirit of the Athens Charter, the third of the 10 'Principles for planning the socialist city' specified the characteristics of the residential units. ${ }^{57}$ Later, in Soviet town planning during the post-war period, the microrayon emerged as the basic planning unit. ${ }^{58}$ The Ideal Communist City, a book initiated in the late 1950s by Alexei Gutnov and other Soviet urban planners and sociologists, shows the renewal of ideas and models related to the new organization of the physical environment that was taking place in Russia. ${ }^{59}$ Also Goldzamt's review of urban culture in Eastern countries during the Socialist period gives key information through its extensive description of housing estates in Eastern cities. ${ }^{60}$ The evolution of the concept from the neighbourhood unit to 'social settlement' and microrayon, explained by Goldzamt, matches with the concept of an ideal and self-sufficient community. The microrayon is considered the basic unit of the residential development, as in Western countries, although it has a different scale. Apart from this question, we can see some specificities but also important similarities with the functionalist and organic urbanism that became dominant internationally. ${ }^{6}$

So, it could be said that housing estates in Eastern bloc cities were as much an expression of modern urbanism as of Socialist urban policies. In particular, those doctrinal formulations that are the basis of the mass housing estates, as Lydia Coudroy de Lille states, precede the establishment of socialism in Europe and differ from Soviet revolutionary urbanism, even though the large housing estates adopt the model of towers and slabs everywhere. De Lille even confers the status of modern city (although out of breath) on 'grands ensembles de la ville socialiste'. ${ }^{62}$ The issue here is that important changes happened after 1955 when Socialist urbanism drastically adopted European radical models of 'open urbanism'. Following the Soviet lead, references to acceptable Western planning models became more common. As S. Ward asserts '... By 1960 modernism's radical roots and 1930s connections with the Soviet Union were also being rediscovered'. ${ }^{63}$ In this sense, it is surprising the degree of experimentalism that, despite the pragmatism that characterized mass housing production in the 1960s, was reached in some Eastern countries, as the projects for Eratrea (1967), Petržalk (1967), and Vilnius (1969) demonstrate. ${ }^{64}$ But these are only exceptions. It is well known that, in opposition to the experimentalism of the interwar period, the production of large housing estates was more a pragmatic option than a 'model of the socialist city'. ${ }^{65}$ As it happened in Western countries, almost everywhere in the Eastern Bloc housing policy was taking a more practical turn towards mass production by the later 1950s. In fact, since the 1960s, the urban and, especially, suburban landscapes of cities of the Eastern Bloc were shaped by the proliferation of some forms characterized by the repetition of standard constructions. ${ }^{66}$ In this regard, authors such as Paul Waley reflect on the similarities between the specific case of New Belgrade with the grands ensembles ${ }^{67}$ But the picture about the impact of international urban planning culture in Eastern cities is still incomplete. ${ }^{68}$

Logically, it is in Moscow where greater continuity with the international modern urban culture can be observed, in spite of attempts during the Stalinist period to differentiate from Western urbanism. Economic criteria determined the election of standard designs for the large-panel and large-block buildings of the 'first generation' of housing estates. Problems associated with prefabrication became evident in the large estates built in the 1960s. In the Kruschev era the commitment to industrialization and prefabrication led to well-known consequences in the urban forms of estates: 
The minimal number of types of flats and apartment houses was adopted ... The density of the construction was not high and the houses 'floated' freely in space, without organizing that space. All these circumstances taken together generated a drab monotony of the residential environment. ${ }^{69}$

As a 'solution' to the problem of monotony, large housing developments were broken up into smaller neighbourhoods, which were arranged in accordance with the same structural scheme: green internal spaces with a mixed construction pattern and a game of contrast between low volumes and verticals towers, etc. The huge area of the Moscow North-East districts of Khimki-Khovrino (1960-1966) and other such as Fili-Izmajlovo or Chorosevo-Mnevniki built in those years can be mentioned as characteristic housing estates of these new trends. ${ }^{70}$

Unlike Russian cities, the rest of the socialist block experienced a certain lack of continuity with the modernist tradition in the post-war period. In the case of German Democratic Republic cities, an important difference lies in the fact that its construction was linked to industrial settlements. In contrast to Western urban models, industry was the 'city builder' according to Soviet urban planning from the early 1930s (for instance Magnitogorsk or the New City of Eisenhüttenstadt in the 1950s). This circumstance introduced a new problem: the cities were abandoned when the factories closed. Another interesting issue is the persistence of still rather closed and compact urban forms, more related to the Wiener Höfe than to the radicalism of slabs - independent of the road network and of the blocks - which have become dominant since then. ${ }^{71}$ In a paradigmatic city such as Berlin, the Cold War capital, we can find one of the most identifying features of Eastern mass housing estates: regardless if they were built in the historical town centre (Fischerinsel, since 1967) or in the outskirts (Marzahn, since 1975) they were charged with the ideology of prefabricated concrete blocks, since the State dictated that this was the preferred system. ${ }^{72}$ However, most of these large estates were located, as in the Western European cities, far away from the centre, what some authors see, with some exception, as a reason for the failure of these new towns: 'The only really successful new town was Halle-Neustadt, attractive because it was near an old large town'. ${ }^{73}$ Talking about number and size of estates, it is important to note that at the time of reunification in 1990 the 17 large prefabricated slab estates housed the majority of East Berlin's population in 270,000 apartments with 700,000 inhabitants. ${ }^{74}$

Also in Poland, probably the socialist country where the modernist planning culture was most important after the War, ${ }^{75}$ the presence of industry was a determining factor: Soviet concepts from the 1920s and 1930s as well as the experiences of the USSR five-year plans ${ }^{76}$ are recognizable in Polish estates. Nowa Huta, the large housing estate in Poland, next to Krakow, is the most significant episode, which tried to learn from both positive and negative Soviet experiences (Figure 8). Given the huge scale of the estate and the autonomous organization of each residential unit (osiedle), ${ }^{77}$ urban forms with very different urban planning coexist. As we have mentioned before, the predominance of the system of streets and squares in the first residential units built in the 1950s contrasts with the open urbanism of the later districts of Bienczyce (50,000 inhabitants) or Wzgorza Krzeslawickie (11,000 inhabitants); this last one was chosen as the image for the cover of Goldzamt's reference book. The succession of linear blocks, regularly arranged in a wide green space and related to a hierarchically organized traffic network, ${ }^{78}$ reveals the legacy of the CIAM urbanism, even if the Athens Charter never directly addressed the issue of the relation between industry and city.

In a similar way as it happened in Polish cites, Prague saw modernist traditions continue after the War. Housing estates (sidliste) such as Solidarita (1947-1949) or Invalidovna (1950-1965) 


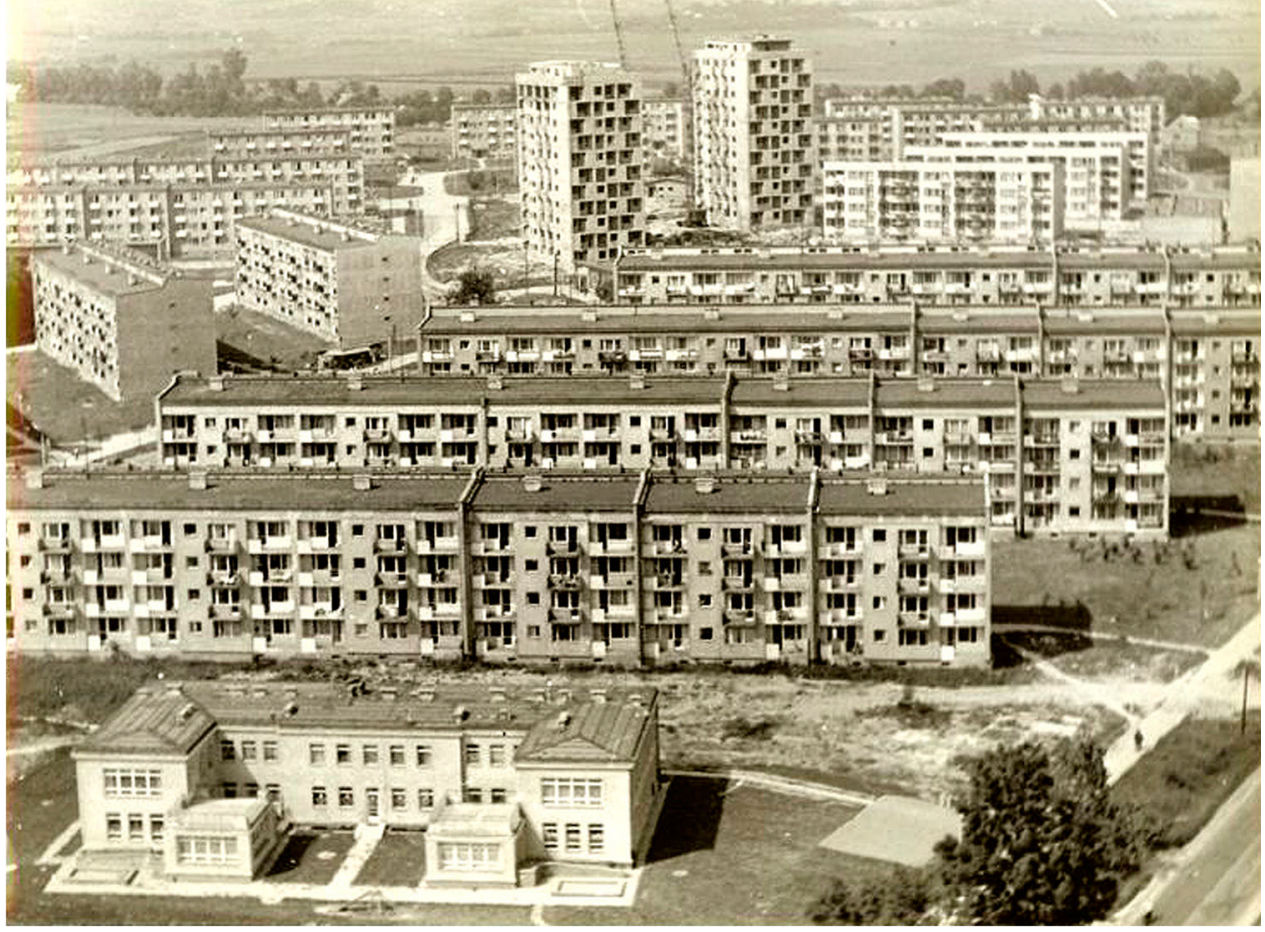

(b)

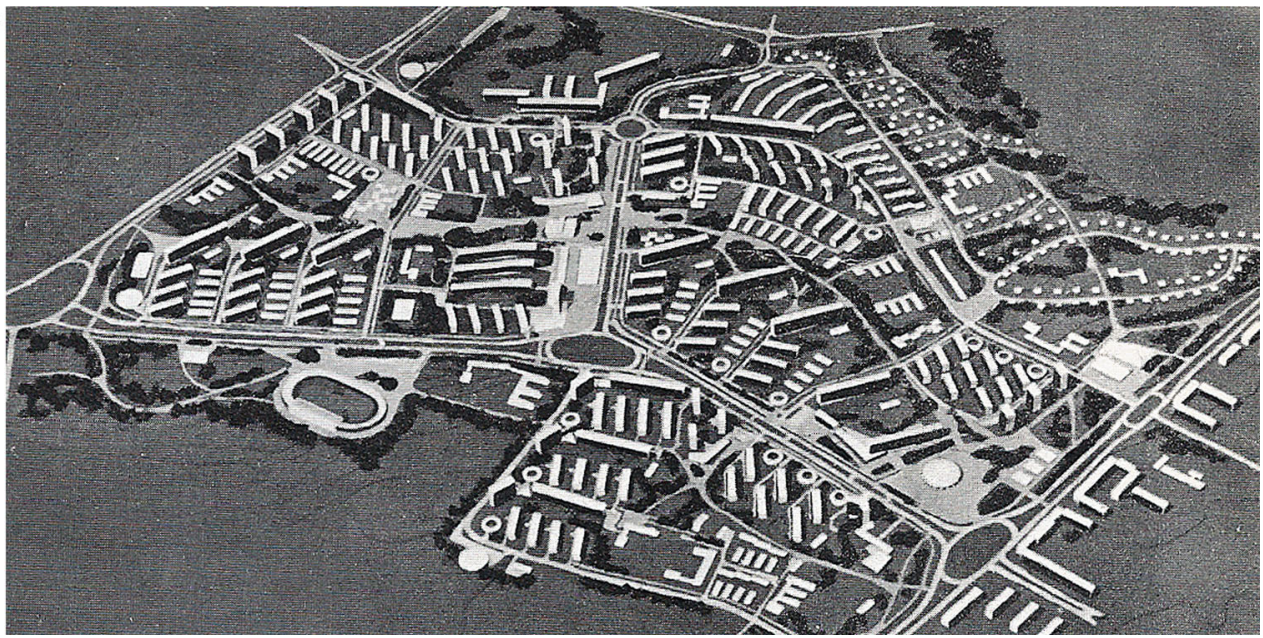

Figure 8. (a and b) Bienczyce, Nowa Huta, Cracow, 1958-1962, 12,500 units. Soviet concepts from the 1920 s and 1930s as well as the experiences of the URSS five-year plans, are recognizable in Polish estates. The huge scale of this estate and the autonomous organization of each residential unit (osiedle) allow different urban forms to coexist (Source: Goldzamt, Edmund. El urbanismo en la Europa socialista. Barcelona: Gustavo Gili, 1980 and Wikimedia Commons). 
are a good examples of this continuity. ${ }^{79}$ In spite of the fact that the monolithic urbanism of the Panelak was dominant, important experimentation took place in the central years of the socialist period, giving rise to some proposals equivalent to those of most quality in the international urban and architectural culture. More recent large-scale estates built in the second half of the 1980s and at the beginning of the 1990s, such as Bohnice, in the Northern part of the city, and Jihozápadni Město (South-west Town), again confirm that these mass housing estates correspond to functionalist and rationalist standards that belong to the international modernist culture, with blocks and towers standing loosely grouped inside quiet zones with playgrounds and greenery (Figure 9).

Housing production in the Ukraine was dependent, as in other Soviet republics, on decisions made by the Ministry of Construction in Moscow. ${ }^{80}$ Therefore, similarities with Russian housing estates were strong, even if there were some experimental housing projects, especially in the 1960s. As in other countries of the Eastern Bloc, cities were planned according to the principles of the 1935 Moscow Master Plan. Large housing estates continued to be an important part of the total housing stock up until the 1980s and their forms were still influenced by the Moscow Plan, mainly in a first generation. ${ }^{81}$ Late housing estates such as the Sykhivs 'kyi district in Lviv, 'one of the integral symbols of the city' which started its building process in the 1970 s, could also be compared to other Western examples. ${ }^{82}$ A singular experience worth mentioning is the Rusanivska mikrorayon in Kiev (1961-1974), planned as a model sleeping district not directly tied to industry. ${ }^{83}$

Recent surveys and visits to these and other housing estates in Eastern Europe cities confirm that their main problem does not lie in the definition of the public spaces and urban design, but rather, in the large scale of the states, in the low quality of the construction, and, in some cases, in the abandonment of the industrial areas they were linked to (Figure 9).

\section{Concluding remarks: similarities and contrasts of a common legacy}

Let us go back to our original question about contrasts and similarities between modernist housing projects in Western and Eastern cities of Europe in the 1960s and 1970s. Looking from a morphological perspective, we find that differences are not so relevant.

The first and obvious difference is that we find more large-scale mass housing projects, with more homogenous housing typologies, in Eastern than in Western cities. It is also remarkable that the quality of construction is lower in the East, mainly for economic reasons. Besides, the State administration commitment to standardization and prefabrication and the prevalent unified code imposed, according with the socialist idea that uniform dwellings were a sign of equality among inhabitants, led to the radical homogeneity and monolithic look of Eastern cities' urban landscapes. As a consequence, a great part of a mixed population lived in the large housing estates of Eastern countries; there are no social ghettos as we find in other Western cities. Nor is it overlooked that the different versions of those urban forms in the East and in the West are also a consequence of distinct urban policies, land possession, possibilities of centralized planning in socialist countries, commitment to prefabrication, etc.

But we should not forget that differences among Western cities themselves exist too. For instance the contrast between housing estates, urban forms, and the morphology of the surrounding neighbourhoods is bigger in most of the North-western and Western central European cities (in Germany, UK, even in France), where high-rise and slabs developments contrast with low density suburbs, than in Southern European cities (in Italy or Spain), where we find more continuities in urban forms. Therefore, the dichotomy West/East or 'capitalist'/'socialist' should be reconsidered. 
(a)

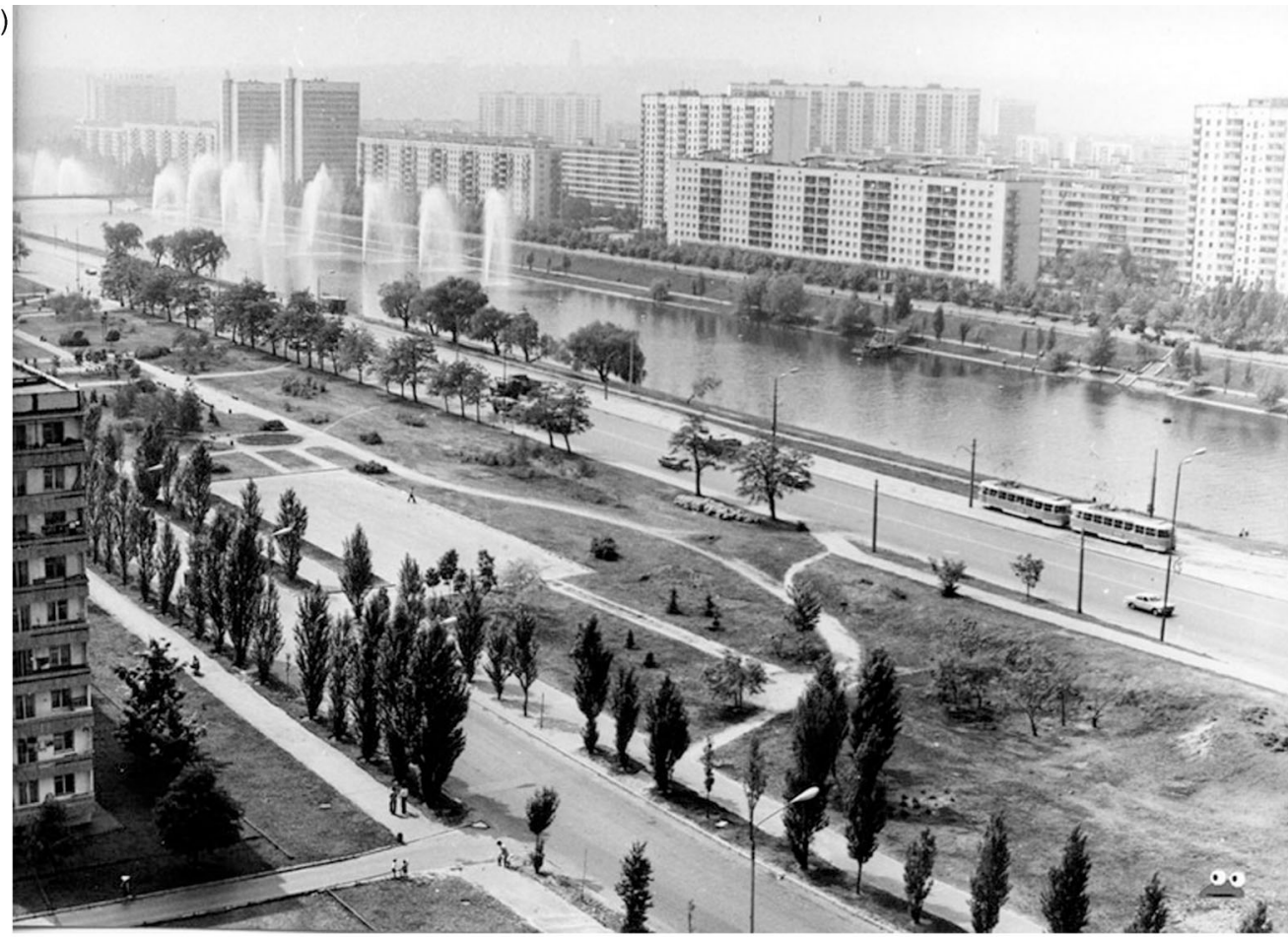

(b)

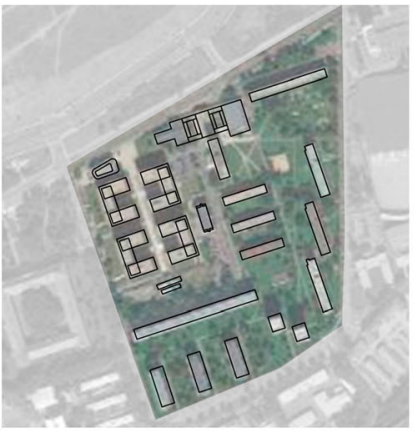

(1)

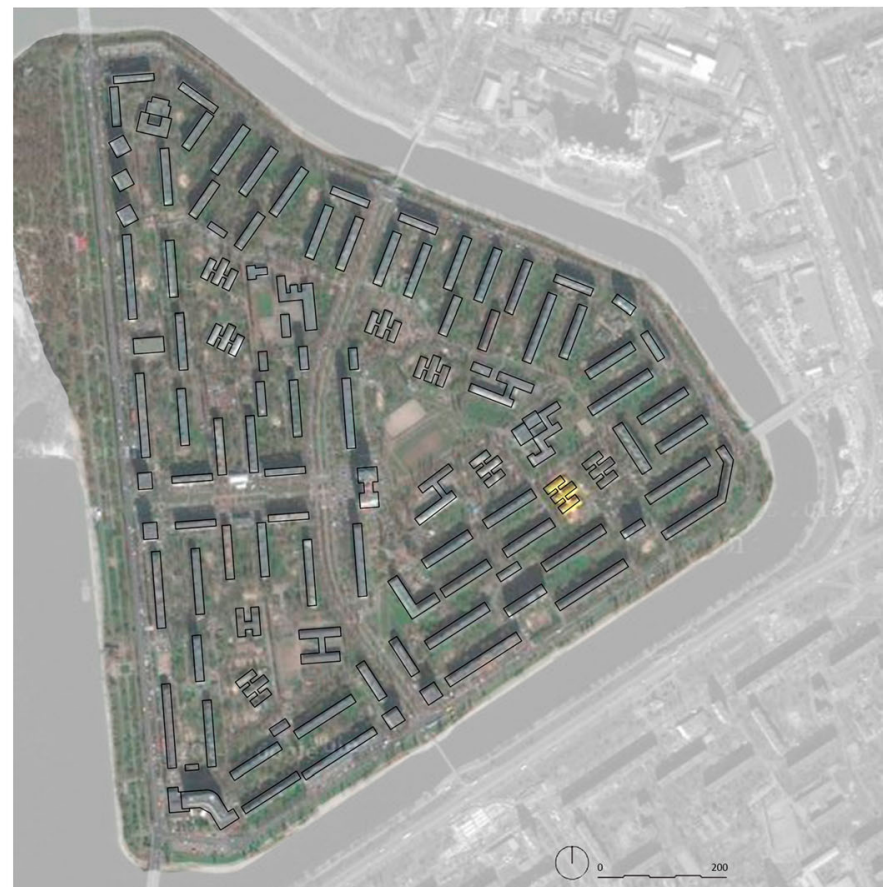

Figure 9. (a) Rusanivska, Kiev, 1961-1974. (a and b) Invalidovna, Prague, 1950-1965, 1000 units (14 ha); Rusanivska, Kiev, 1961-1974, 11,250 units in blocks ranging from 9 to 16 storeys ( 84 ha). As in the 


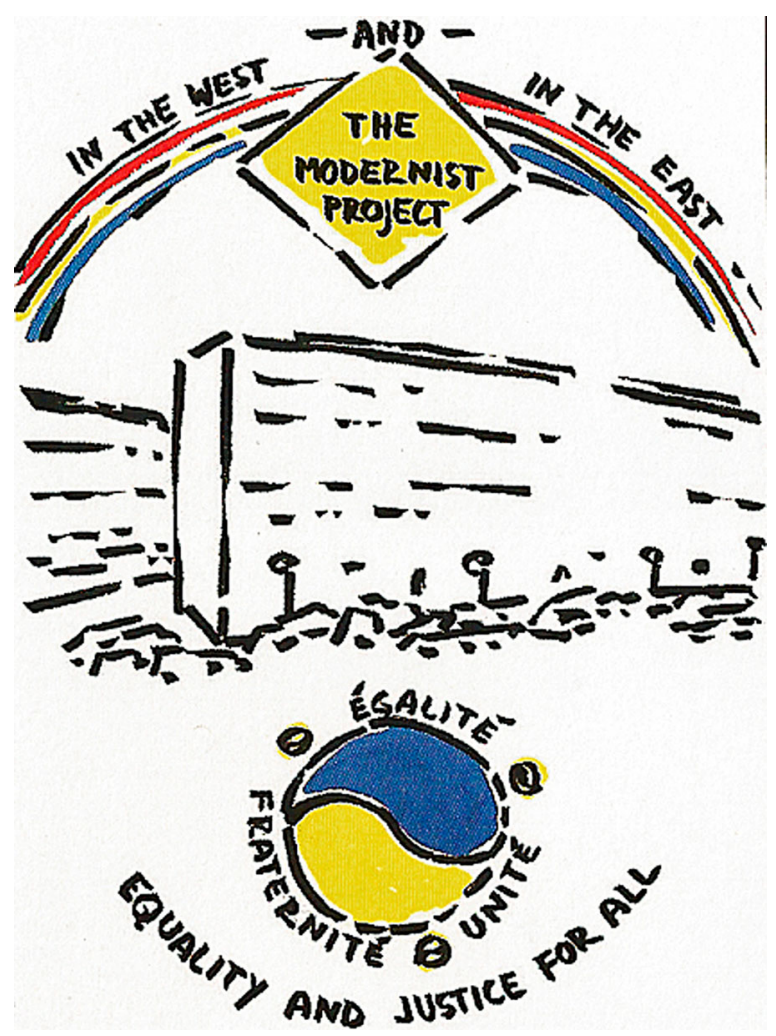

Figure 10. 'The Modernist Project', Marjetica Potrč, 2006. Art and literature show how paradoxically similar urban forms are able to serve different ideologies. Potrč's engaged work is a critical response to the changes imposed by global political and economic structuring and demands equality and justice for all ... in the West and in the East (Source: Kjeldsen, K. (curator). Frontiers of Architecture III-IV: Living. Louisiana: Exhibition Catalogue, 2001. Private collection of the authors).

Nevertheless, despite those differences between West and East in the referred period, parallels with the application of urban design strategies close to the most radical modernist CIAM tenets are evident in both sides of the Iron Curtain. In fact, similarities in housing estates urban forms built everywhere in the 1960s and 1970s are evident. As Wassenberg stated, high-rise estates dominated the building in that era and there has never been a period in house building in which the similarities between countries have been as great. ${ }^{84}$ Actually, the strategies and experimentation in applying CIAM principles were similar in the East and in the West. And also the strong contrast between the great experimentation of early post-war examples and the growing standardization and radicalization of the projects of the 1960s and 1970s, which led to a vulgarization of the Athens Charter, was a similar process in the East and in the West. Of course there are some interesting and successful examples, but they are only exceptions in a landscape of low quality projects which characterize almost all European city peripheries built in that period of accelerated urban growth. 
It seems clear that the responsibility of modernist urban culture for the significant loss of environmental quality and urbanity in the estates built in those decades must be carefully defined: modern urban planning began to fail as the CIAM tenets became more radical, larger, and standardized, and consequently when urban design was developed with evident less care. Even if it sounds too generic and should be nuanced, we share Rem Koolhaas critical view applied to that years, especially regarding large-scale housing estates: 'Modernism's alchemistic promise - to transform quantity into quality through abstraction and repetition has been a failure, a hoax: magic that didn't work. Its ideas, aesthetics, strategies are finished' ${ }^{85}$

In this regard, it is interesting to consider the diagnosis of present day housing estates made by the European Commission. The establishment of international networks, such as Restructuring Large Housing Estates in European Cities (RESTATE), ${ }^{86}$ evidence the relevance and intellectual complexity of the modernist housing estates legacy, with similar problems in the East and in the West related to the commitment with radical modern urban forms, an issue that needs to be addressed with clarity and creativity.

At any rate the international validity of the modernist models may end up being ambiguous and paradoxical. Art and literature show how similar urban forms can serve different ideologies. Let us conclude with some quotations from this respect that make reference to ironies and ambivalences of history. Brigitte Reimann writes in her diary about Berlin: 'I have a suspicion: Modern architecture looks like in West and in East'. Also the Spanish writer Javier Pérez Andújar when he refers to Barcelona's outskirts expresses himself as follows: 'A landscape interchangeable with other cities all over the world ... Before feeling part of a country, of a fatherland or of nation, I intend to belong to the International of the slabs'. Along the same lines, the Slovenian artist Marjetica Potrč reveals ironically the utopian nature of 'The Modernist Project': equality and justice for all ... in the West and in the East ${ }^{87}$ (Figure 10).Figure 10).

\section{Acknowledgements}

This article is an edited and extended version of the paper given at the 12th International Conference on Urban History Cities in Europe, Cities in the World, European Association for Urban History, Lisbon, Portugal, 3-6 September 2014 (see note 2). This research has been carried out within the framework of the research project UR_HESP (Urban Regeneration of Housing Estates in Spain, project number $\mathrm{I}+\mathrm{D}+\mathrm{i}$ BIA2014-60059-R) directed by the authors of this text and granted by the Ministry of Economy, Competitiveness of Spain. The authors thank Lydia and Laurent Coudroy de Lille de Lille for their help as well as the anonymous reviewers and the Editor-in-Chief of Planning Perspectives for their critical yet constructive comments.

\section{Disclosure statement}

No potential conflict of interest was reported by the authors.

\section{Notes}

1. Goldzamt, Urbanistyka krajów socjalistycznych. In this book Goldzamt develops social and socialist ideas that had previously addressed in earlier publications such as William Morris and the Social Origins of Modern Architecture (Warsaw, 1967) or Social Aspects of Town Planning and Housing in Italy (Warsaw, 1968).

2. 'Housing estate', is a concept which lacks a simple definition and has not even a single meaning in every country. Some authors refer to 'areas of concentrated high-rise housing', but this is not enough 
if we want to understand its urban meaning. It is on French Grands Ensembles where we can find a deeper reflection on the meaning of the concept: 'L'expression ne désigne pas un mode d'edification, mais plutôt une forme et un payssage caractérisé para un regroupment de barres et de tours sur un espace soumis aux règles du zonage', Dufaux and Fourcaut, Grands Ensembles and VieillardBaron, "L'origine des grands ensembles." From a planning history approach there is a definition on housing estates or Polígonos de Viviendas in Spain: 'Unified developments, made by similar tower and slabs ensembles built in a short time on unified plots of land, through a unified management and a global Project', Terán, Historia del Urbanismo, Vol. 3, 228.

3. A reduced version of the ideas developed in this text can be found in our paper submitted to the 12th International Conference on Urban History; Cities in Europe, Cities in the World (European Association for Urban History, Lisbon, Portugal, September 3-6, 2014).

4. Among the existing literature some sectorial analysis focused in specific episodes can be mentioned, as AA.VV, 10 Stories of Collective Housing; there are some general studies on soviet cities with a socialist approach, as Goldzamt, Urbanistyka krajów socjalistycznych, an important book that however is not translated in English, or French and Hamilton, The Socialist City and Bater, The Soviet City. Some works tackle post-war urbanism, such as Mumford, The CIAM Discourse; others deal with mass housing estates or grand ensambles in France, as Dufaux and Fourcaut, Grands Ensembles; there are also some global visions on housing estates in the twentieth century in form of grand narrative, such as Hall, Cities of Tomorrow, especially the Chapter 7 "The City of Towers"; some other address more systematic approaches on modern urbanism in the context of planning in the twentieth century, such as Ward, Twentieth-Century City, which gives an international comparative perspective; others pay attention to the varied ways in which architecture and urban planning interacted with the different regimes of welfare provision, such as Swenarton, Avermaete and van den Heuvel, Architecture and Welfare State; a global perspective comparing several cities can be found in Florian Urban, Tower and Slab.

5. 'Il faut bien distinguer La Charte d'Athènes de sa vulgate;' Paquot et al., "La Charte d'Athènes," 62.

6. A parallel approach can be found in the case of international expos, which in spite of being "exceptional urban episodes' can be seen, at the same time, as urban design paradigms. Freestone and Amati, Exhibitions and Monclús, "International Exhibitions."

7. See some of our previous studies on urban forms and housing estates in Western European cities: Monclús et al., Paisajes Urbanos Residenciales; Guàrdia, Monclús and Oyón, Atlas Histórico de Ciudades; Sambricio, La Construcción; Díez, "Zoom In-Zoom Out," 75-106; Díez, "Sobre la reconstrucción italiana," 37-44; Díez, "La Influencia Centroeuropea," 138-61; "El Modelo Vienés," 172-5; and "Barrio de la Estrella," Vol. II, 114-5.

8. Koolhaas, Fundamentals. Other recent references to the development of the debate of urban planning cultures in different countries: Freestone and Amati, Exhibitions and Sanyal, Comparative Planning Cultures.

9. RESTATE, Rowlands, Musterd and van Kempen, Mass Housing in Europe. Even if the authors speak about 'areas of concentrated high-rise housing ... post-war developments, carefully planned', it does not imply that these areas were so 'well planned' too.

10. Hebbert, "The Street as Locus," 581-596.

11. Frampton, Modern Architecture; Mumford, The CIAM Discourse; Fishmann, Urban Utopias; Gold, The Experience of Modernism; and Monclús, "International Exhibitions."

12. Le Corbusier's Ville Contemporaine (1922) or L. Hilberseimer's Verticalstadt (1924) are paradigmatic examples.

13. Hilpert, Die Funktionelle Stadt.

14. Grundsätze des Städtebaus. Von der Regierung der Deutschen Demokratischen Republik am 27. Juli 1950 beschlossen' in von Beyme et al., Neue Städte aus Ruinen, 30-1. An English translation of the sixteen principles can be found in Clelland, "From Ideology to Disenchantment," 41-5. An abstract is available in Strobel, "From Cosmopolitan Fantasies."

15. Consequently, they are organized with a meaningful structure. Instead of the four key functions of the city proposed in the Athens Charter, the socialist version deals first with the historical nature of the city; second, with 'housing estate' forms and desirable characteristics; third, with the urban 
'atmosphere' of the city (as opposed to the non-urban atmosphere of the garden city); fourth, with the basis for a specific urban design in contrast to more abstract urban diagrams.

16. Strobel, "From Cosmopolitan Fantasies," 128.

17. We could also mention another paradox of historic nature. If we think on the origin of socialist dwelling projects, such as the Red Vienna Höfe, we see how this architectural episode was generally rejected just because of its socialist rhetorical language and the distance from the proposals for a new way of living that the Weimerer Republik was developing. Nevertheless Red Vienna Höfe have stood the test of time and is generally considered a success regarding its urban form. Díez, Complicidades en arquitectura.

18. Mumford, The CIAM Discourse; Mumford, "CIAM Urbanism," 391-417; Wakeman, "Rethinking Postwar Planning History," 153-63; Orillard, "The Transnational Building," 209-29; and Paquot et al., "La Charte d'Athènes, et après".

19. Jacobs, The Death and Life of Great American Cities; Cullen, The Concise Townscape; Alexander, "A City is Not a Tree"; Rossi, The Architecture of the City; Mitscherlich, Die Unwirtlichkeit unserer Städte. Critical views have become established in the reference literature, as in Hall's, Cities of Tomorrow; and other recent works such as Wassenberg, Large Housing Estates. Among the critical visions against the tower and slab urbanism, some architects as Vittorio Magnago Lampugnani propose the recovering of the urban block even in the outskirts of the city. Lampugnani, "Stadt oder Suburbia?", 10-27.

20. López de Lucio, Vivienda colectiva, 330.

21. 'It is not the priest - and this is how we must consider the precursors of functionalism - who failed, but the believers who, with their absolutism and lack of imagination, failed to have the courage to make a critical adaptation of their mission'; Bollerey, "Decorations Have Become Superfluous," 45.

22. Urban, Tower and Slab, 17.

23. Ward, Planning the Twentieth-Century City, 241.

24. Hall, Cities of Tomorrow.

25. Ibid., 204-28.

26. Banham, "Park Hill. Sheffield"; see also Banham, Megastructure.

27. Gold, The Practice of Modernism, 170.

28. However, the middle-size scale allows an easier control of the public spaces and facilitate the development of regeneration programmes. About the regeneration that is already being carried out, see Urbansplash transformation, Riba Publishing http://www.urbansplash.co.uk/residential/park-hill (last accessed May 2015).

29. Wagenaar, Town Planning, 430; Ibelings, 20th Century Urban Design; Helleman and Wassenberg, "Tomorrow's Idealistic City," 3-17.

30. Galindo, Cornelis van Eesteren.

31. The major part of the housing estate has been demolished and replaced by new housing and shopping areas. Works started at the beginning of the 1980s. It is considered one of the main regeneration projects of a modernist European housing estate.

32. Huge open spaces, traffic segregation (three levels), a high number of housing units (13,000 dwellings in 10-storey high-rise apartments) with minimal typological variations, mega corridor structures, radical geometry, etc.

33. Koolhaas, $S, M, L, X L, 863$.

34. France deserves a special attention because of the particular episode of the grands ensembles, and the ZUPs (Priority Urban Zones). Both initiatives resulted in a sharp increase in construction. The adoption of modern urban renewal criteria in parallel to the new dominant urban forms in the banlieues (residential suburbs), make Paris an exceptional case study. Dufaux and Fourcaut, Grands Ensembles.

35. Ibid. Several issues of the journal Urbanisme have focused on this subject: "Le grand ensemble, histoire et devenir", Urbanisme 322, 2002; "La Charte d'Athènes et après?", Urbanisme 332; "Paris/ Banlieues", Urbanisme 333, 2003. André Bloc, head of the prestigious journal L'Architecture d'Aujour-Hui, criticized the grands ensembles as "cities without soul", as early as 1962 (quoted 
by Piccinato, La arquitectura contemporánea en Francia, 154; Florian Urban dates the shift of public opinion between 1958 and 1962; and Urban, Tower and Slab, 51).

36. Merlin, Les villes nouvelles en France, 330; 1945-1975, Une histoire de l'habitat. 40 ensembles «Patrimoine du XX siècle», Exposition présentée à La Maison de l'architecture en Île-de-France, du 5 juillet au 15 septembre 2011; Thomé, Créateurs d'utopies and Stébé, "Les Grands Ensembles."

37. Bielka and Beck, Heimat Großsiedlung. See specially Mäckler, "Städtebauliches Gutachterverfahren Gropiusstadt Süd," 244-51.

38. Bodenschatz, Städtebau in Berlin.

39. Urban, Tower and Slab, 59.

40. With emphasys in 'projects', rather than in 'plans'. Benevolo, Longo, and Melograni, I modelli di progettazione.

41. As Forte Quezzi in Genova, Quartiere Comasina in Milan, Quartiere San Polo in Brescia, Zen in Palermo, Rozzon Melara in Trieste, Le Vele di Scampia in Napoli, Tor Vergata in Rom, etc.

42. L'architettura cronache e storia $248,78-88$. The housing estate was built by GESCAL, Gestione case per lavoratori (management of social housing), a fund created in 1963 gathering the heritage of INA-casa.

43. Montaldo, "Quartiere Gescal di Quarto Cagnino," 80-5.

44. Lucchini, "The Quarto Cagnino District in Milan (1964-1973)."

45. Hebbert, "Town Planning vs Urbanismo."

46. Moneo, Vivienda y Urbanismo en España.

47. Cortés, "Modernidad y vivienda en España."

48. Ferrer, "The Undeserved Credit of the Housing Estate."

49. See López de Lucio, "El Gran San Blas" and Sambricio and Lampreave, 100 años de historia de la intervención, 136.

50. See AA.VV, Gran San Blas.

51. Busquets, La construcción urbanistica, 264.

52. Tena, Universalidad y adecuación en la obra de LIGS, 137-61.

53. Ramos, "Polígonos de vivienda."

54. Monclús, Labarta, and Díez, Proposals for Balsas de Ebro Viejo.

55. Bosma, "New Socialist Cities," 311.

56. Quilici, Ciudad rusa y ciudad soviética, 262-3.

57. Bater, The Soviet City, 27-8 (1. Limited city size, 2. State control of housing, 3. Planned development of residential areas, 4. Spatial equity in the distribution of items of collective consumption, 5. Limited journey to work. 6. Stringent land-use zoning, 7. Rationalized traffic flow, 8. Extensive green space, 9. Symbolism and the central city, 10. Town planning as an integral part of national planning).

58. In the Moscow Plan (1935) these microrayon units (8000-12,000 residents) are composed by five to eight 'super blocks' or living complexes, each with a population of 1000-1500 inhabitants. See Bater, The Soviet City, 102. Some precisions on Moscow Plan and the role of kvartal or super block can be found in Quilici, Ciudad rusa y ciudad soviética, 263; see also Minkevičius, Cities Yesterday, Today, and Tomorrow; and also Dremaite and Petrulis, "Modernism in Soviet Lithuania."

59. Gutnov et al., The Ideal Communist City.

60. Goldzamt, El urbanismo en la Europa socialista.

61. 'In some cases, though, a valuable living environment was achieved, but almost entirely thanks to the concepts of progressive urbanism, rather than through the architecture of individual blocks', Moravčíková, "Concentrated Responses," 22-9.

62. "Ces colonies, cités, prototypes de la construction standarisée sont donc avant tout dans leurs fondements une expression de la modernité europeene, et non du "socialisme"", Dufaux and Fourcaut, Le monde des grands ensembles. Coudroy de Lille, "Une ideologie du pré-fabriqué?," 90-1.

63. Ward, "Soviet Communism," 499-524.

64. The Eratrea project was presented in the Czech pavilion of the 1967 International Montreal Expo (E. Goldzamt, op. cit., p. 316); in Petržalone took place one of the main international competitions on a large-scale housing estate in 1967; the Lazdynai residential district built in Vilnius, Lituania, 
reveals French, Swedish, and Finnish urban planning influences, see Dremaite and Petrulis, "Modernism in Soviet Lithuania."

65. "La dimension utopique était en comparaison beaucoup plus forte dans les ouvrages et réalisations de l'entre-deux-guerres en Europe centrale », "Une ideologie du pré-fabriqué?," 92.

66. Dufaux and Fourcaut, Le monde des grands ensembles. Amestoy, "Les Grands Ensembles en Russie."

67. "Neither were these buildings so different, however, from the grands ensembles built around Paris, Lyon and other French cities," Waley, "From Modernist to Market Urbanism," 209-35.

68. Wakeman, "Rethinking Postwar Planning History," 153-63.

69. Ikonnikov, Russian Architecture, 282.

70. See Moscow Microrayon Masterplan Development: http://microrayon.wikispaces.com/Moscow+ Microrayon+Masterplan+Development, accessed July 2014.

71. Something similar happened in Spain during the first years of Franco Dictatorship, particularly in Madrid. From 1939 to the mid-fifties, the housing estates promoted by the State were compact forms coinciding with the city blocks.

72. Urban, Tower and Slab, 69.

73. Diefendorf, Rebuilding Europe's Bombed Cities. von Beyme, "Reconstruction in the German Democratic Republic," 192.

74. Schuemer-Strucksberg, "Socialist Large Scale Estates in East Berlin."

75. Goldzamt emphasizes the contribution of Polish architects to the Athens Charter, such as Syrkus, Brukalski, and Piotrowski. Goldzamt, El urbanismo en la Europa socialista, 171.

76. Ibid., 169-71.

77. The word 'mikrorayon' was never adopted in Poland. Instead of it, the Polish word 'osiedle', which was redefined by Polish 'modern' architects before the war was always used. We thank Lydia Coudroy de Lille for this information.

78. Goldzamt, El urbanismo en la Europa socialista, 266-7.

79. Ibidem, 262-3.

80. Volodymyr-Durmanov, "Housing Development."

81. Some data can illustrate the process:

From 1965 to 1973 the share of large-panel buildings in state-constructed and co-operatively constructed housing increased from $29 \%$ to $44 \%$, which, considering all housing production was an increase from 19\% to $31 \%$. By 1975, about forty types of large-panel buildings had been developed. At the end of the 1970s the famous 5 and 12-storey series using pre-fabricated construction were introduced. The present high-rise type dominant in the Ukraine is the socalled multi-section building with 5 or more sections of 5 or 9 -storeys.

Durmanov and Dubbeling, Ukraine, 206.

82. Bielka and Beck, Heimat Großsiedlung. Cherkes, "Socialist Birth and Afterlife," 54-63.

83. Located on the left bank of the Dnieper River in a territory panned out with sand, it was thought as a district without private cars, served by buses and river boats on Dnieper and canal.

84. Wassenberg, Large Housing Estates.

85. Koolhaas, "What Ever Happened to Urbanism?," 959/971.

86. RESTATE: good practices and new visions for sustainable neighbourhoods and cities, see Rowlands, Musterd and van Kempen, Mass Housing in Europe.

87. Reimann and Henselmann, Briefwechsel; Pérez Andújar, Paseos con mi madre; Marjetica Potrč, "Pristhtina House", in Kjeldsen, Frontiers of Architecture III-IV: Living, 152.

\section{Notes on contributors}

Javier Monclús (Zaragoza, 1951) is Dr Architect and Full Professor of Urbanism at the School of Engineering and Architecture, University of Zaragoza (Spain), where he is now Chair of the Department of Architecture. Professor of Urbanism at the Polytechnic University of Catalonia in Barcelona (1980-2005). He was previously a planner and worked with the Consortium Zaragoza Expo 2008 
(2005-2009). He has published widely on Planning, Urban Design and Urban Planning History issues, among them: "International Exhibitions and Urban Design Paradigms," in M. Amati, R. Freestone, eds., Exhibitions and the Development of Modern Planning Culture (2014); International Exhibitions and Urbanism: The Zaragoza Expo 2008 Project (2009); and co-edited Culture, Urbanism and Planning (2006). He is member of the Editorial Board of Planning Perspectives and was the 11th International Planning History Society's (IPHS) Conference Convenor (Barcelona 2004). He is interested in urban projects, landscape urbanism, planning history and theories of urbanism.

Carmen Díez Medina (Madrid, 1962) is architect (ETSA Madrid, 1988). Ph.D. at the Technische Universität Wien, TU (1992-1996), Fakultät für Raumplanung und Architektur. Collaborating architect by Nigst, Hubmann\&Vass in Viena (1998-1994) and by Rafael Moneo in Madrid (1996-2001). Chair of the Department of Theory and Projects in Architecture and Urbanism in the University CEU San Pablo, Madrid (2007-2009). Since 2009 she is Associate Professor of Architectural History of the Department of Architecture at the School of Engineering and Architecture, University of Zaragoza (Spain). She has lectured at doctorate courses and international seminars at the Politecnico di Milano, Technische Universität Kaiserslautern, Seconda Università degli Studi di Napoli Luigi Vanvitelli, Technische Universität Karlsruhe, Moscow Stroganov Akademy and University College Edimburg. Her publications focus on architectural history, social housing and cultural landscapes. At the moment both authors are directing a research project granted by the Spanish Ministry of Economy and Competitiveness on urban regeneration in Spanish mass housing estates.

\section{References}

AA.VV. 10 Stories of Collective Housing. Graphical Analysis of Inspiring Masterpieces. Vitoria: a $+\mathrm{t}$ Architectural Publishers, 2013.

AA.VV. Gran San Blas. Análisis sociourbanistico de un barrio nuevo españool [Gran San Blas housing estate. Sociourbanistic survey of a new Spanish neighborhood] supplement of Arquitectura. no. 113114 mayo-junio. Madrid: COAM, 1968.

Alexander, Christopher. "A City is Not a Tree." Architectural Forum no. 172, 1965.

Amestoy, I. "Les grands ensembles en Russie, de l'adoption dún modèle à la desáffection [Great housing estates in Russia, from adoption to disaffection of a model]." In Le monde des grands ensembles [The world of large housing estates], edited by Frédéric Dufaux and Annie Fourcaut, 129-141. Paris: Créaphis, 2004.

Banham, Reyner. "Park Hill. Sheffield.” AR. The Architectural Review, December 1961.

Banham, Reyner. Megastructure: Urban Futures of the Recent Past. London: Thames and Hudson, 1976. Bater, James H. The Soviet City. London: Edward Arnold, 1980.

Benevolo, Leonardo, Giura Longo, and T. Melograni. I modelli di progettazione della città moderna [Modern city design models]. Venezia: Tre lezioni, Cluva, 1969.

von Beyme, K. "Reconstruction in the German Democratic Republic." In Rebuilding Europe's Bombed Cities, edited by J. M. Diefendorf, 190-208. London: Macmillan, 1990.

von Beyme, K., et al. Neue Städte aus Ruinen: Deutscher Städtebau der Nachkriegszeit [New cities from the ruins. German urban planning of the post-war period]. Munich: Deutscher Taschenbuch Verlag, 1991.

Bielka, F., and C. Beck (Hg.). Heimat Großsiedlung. 50 Jahre Gropiusstadt Entwicklungsmöglichkeiten für die Zukunft [Homeland large housing estates. 50 years gropiusstadt possibilities of development for the future of Berlin]. Berlin: Nikolai Verlag, 2012.

Bodenschatz, Harald. Städtebau in Berlin. Schreckbild und Vorbild für Europa [Urban Planning in Berlin. Horror and Model for Europe]. Berlin: Dom Publishers, 2010.

Bollerey, Franceska. "Decorations Have Become Superfluous." UR 8 (1989): 40-45.

Bosma, Koos. "New Socialist Cities: Foreign Architects in the USSR 1920-1940." Planning Perspectives 29, no. 3 (2014): 301-328. 
Busquets, Joan. La construcción urbanística de una ciudad compacta [The building of a compact city]. Barcelona: Serbal, 2004.

Cherkes, Bohran. "Socialist Birth and Afterlife of Largest Lviv District of Sykhiv / Sozialistische geburt und das leben danach: die Großsiedlung in Lwiw." In Heimat Großsiedlung. 50 Jahre Gropiusstadt Entwicklungsmöglichkeiten für die Zukunft, edited by F. Bielka and C. Beck (Hg.), 54-63. Berlin: Nikolai Verlag, 2012.

Clelland, D. "From Ideology to Disenchantment." Architectural Design 52, no. 11/12 (1982): 41-45. Cortés, Juan Antonio. "Modernidad y vivienda en España [Modernity and housing in Spain]." In La vivienda moderna. Registro DOCOMOMO Ibérico 1925-1965 [Modern housing. Listed buildings DOCOMOMO Ibérico 1925-1965], edited by AA.VV, 11-34. Madrid: Arquia, 2009.

Coudroy de Lille, Laurent. "Une ideologie du pré-fabriqué? [An ideology of prefabricated]" In Le Monde des Grands Ensembles [The world of large housing estates], edited by Frédéric Dufaux and Annie Fourcaut, 90-96. Paris: Créaphis, 2004.

Cullen, Gordon. The Concise Townscape. London: Architectural Press, 1961.

Diefendorf, Jeffry M. Rebuilding Europe's Bombed Cities. London: Macmillan, 1990.

Díez, Carmen. "La influencia centroeuropea y la Ley Salmón (1927-36) [Central European influence and the 'Salmón' Law (1926-36)]." In Un siglo de vivienda social (1903-2003) [A century of social housing (1903-2003)], edited by Carlos Sambricio, Vol. I, 138-161. Madrid: Nerea, 2003 ("El modelo vienés", ibid. 172-175; "Barrio de la Estrella", ibid. Vol. II, 114-115).

Díez, Carmen. "Reflexiones sobre la reconstrucción italiana a partir de la experiencia del Tiburtino en Roma [Reflections on Italian reconstruction: Tiburtino's neighborhood experience]." Arquitectura 301: Revista del Colegio Oficial de Arquitectos de Madrid, no. 301 (1995): 14-19.

Díez, Carmen. Complicidades en arquitectura, los guiños del arquitecto [Complicity in architecture. The winks of the architect]. Madrid: CEU ediciones, 2004.

Díez, Carmen. "Zoom in-zoom out. Viena/Milán: dos proyectos, dos ciudades [Zoom in-zoom out. Vienna/Milan: two projects, two cities]." In La construcción de la ciudad liberal. ¿... Invertir capital en busca de renta segura?, edited by Carlos Sambricio, 75-106. Madrid: Lampreave, 2009.

Dremaite, Maria, and V. Petrulis. "Modernism in Sovet Lithuania: The Rise and Fall of Utopia." ALF 02, Modernism: Between Nostalgia and Criticism. Vilnius, 2013. Last accessed May 2015. http://www. archfondas.lt/leidiniu/en/alf-02/dmarija-dremaite-and-vaidas-petrulis-modernism-soviet-lithuaniarise-and-fall-utopia\#.

Dufaux, Frédéric, and Annie Fourcaut, eds. Le Monde des Grands Ensembles [The world of large housing estates]. Paris: Créaphis, 2004.

Durmanov, V., and D. Dubbeling. "Ukraine Inheritance of Centralised Planning." In High-rise Housing in Europe. Current Trends and Future Prospects, DUP Science, edited by R. Turkington, R. van Kempen, and F. Wassenberg, 203-214. Delft: TU Delft, 2004.

Ferrer, Amador. "The Undeserved Credit of the Housing Estate.” In Contemporay Barcelona 1856-1999, edited by Mateo, José L., 150-151. Barcelona: CCCB, 1996.

Fishmann, R. Urban Utopias in the Twentieth Century: Ebenezer Howard, Frank Lloyd Wright and Le Corbusier. Cambridge: MIT Press, 1982.

Frampton, Kenneth. Modern Architecture: A Critical History. New York: Oxford University Press, 1980.

Freestone, Robert, and Marco Amati, eds. Exhibitions and the Development of Modern Planning Culture. Abingdon: Ashgate, 2014.

French, A. R., and E. I. Hamilton, eds. The Socialist City: Spatial Structure and Urban Policy. New York: John Willey \& Sons, 1979.

Galindo, Julián. Cornelis van Eesteren. La experiencia de Amsterdam [The Amsterdam experience]. Madrid: Arquia, 2003.

Gold, John R. The Experience of Modernism. Modern Architects and the Future City 1928-1953. London: E \& F Spon, 1997.

Gold, John R. The Practice of Modernism: Modern Architects and Urban Transformation, 1954-1972. New York: Routledge, 2007.

Goldzamt, Edmund. Urbanistyka krajów socjalistyczNew Yorkch: problemy spoleczne [Urban planning in socialist countries]. Warszawa: Arkady, 1971 (Germ.: Städtebau sozialistischer Länder. Soziale 
Probleme. Berlin: Verlag für Bauwesen, 1974 [Stuttgart: Deutsche Verlags Anstalt, 1975]; It. L'urbanistica dei paesi socialisti. Città, territorio e struttura sociale. Milano: Gabriele Mazzotta ed., 1977; Sp. El urbanismo en la Europa socialista. Barcelona: Gustavo Gili, 1980).

Gropius, Walter. "Flach, Mittel, oder Hochbau?" In CIAM III, Brussels, 1930, in AA.VV. Rationelle Bebauungsweisen [Rational Land Development], Stuttgart: J. Hoffman, 1931; Spanish ed.: Aymonino, Carlo. (Ed.). 1973. La vivienda racional. Ponencias de los congresos CIAM 19291930. Barcelona: Gustavo Gili, 1973.

Guàrdia, Manel, Javier Monclús, and José Luis Oyón. (dir.). Atlas histórico de ciudades europeas [Historical atlas of European cities], Vol. I, Península Ibérica [Iberian Peninsula], Barcelona: CCCB-Salvat, 1994; Vol. II, Francia, Barcelona: CCCB-Salvat-Hachette, 1996.

Gutnov, A., et al. (1968 Italian version). The Ideal Communist City. New York: George Braziller, 1971. Hall, Peter. Cities of Tomorrow: An Intellectual History of Urban Planning and Design in the Twentieth Century. Hoboken, NJ: Blackwell, 1988.

Hebbert, Michael. "The Street as Locus of Collective Memory." Environment and Planning D: Society and Space 23, no. 4 (2005): 581-596.

Hebbert, Michael. "Town Planning vs Urbanismo." Planning Perspectives 21, no. 3 (2006): 233-251. Helleman, G., and Franz Wassenberg. "The Renewal of What Was Tomorrow's Idealistic City. Amsterdam's Bijlmermeer High-rise." Cities 21, no. 1 (2004): 3-17.

Hilpert, Tilho. Die Funktionelle Stadt. Le Corbusiers Stadtvision. Bediengungen, Motive, Hintergrunde

[The functional city. Le Corbusier's vision of the city. Conditions, grounds, backgrounds].

Braunschweig: Vieweg, 1978.

Ibelings, Hans. 20th Century Urban Design in the Netherlands. Rotterdam: NAI, 1999.

Ikonnikov, A. Russian Architecture of the Soviet Period. Moscow: Radugacop, 1998.

Jacobs, Jane. The Death and Life of Great American Cities. New York: Random House, 1961.

Kjeldsen, K. (curator). Frontiers of Architecture III-IV: Living. Louisiana: Exhibition Catalogue, 2001. Koolhaas, Rem. OMA, (with Bruce Mau), S, M, L, XL. New York: The Monacelli Press, 1995.

Koolhaas, Rem. "What Ever Happened to Urbanism?" In OMA, (with Bruce Mau), $S, M, L, X L$, edited by Rem Koolhaas, 959/971. New York: The Monacelli Press, 1995.

Koolhaas, Rem. (curator). Fundamentals. Absorbing Modernity: 1914-2014. Venezia: Marsilio, Rizzoli, 2014.

Lampugnani, Vittorio Magnago. "Stadt oder Suburbia [City or Suburbia]?" ZARCH. Journal of Interdisciplinary Studies in Architecture and Urbanism, no. 3 (2014): 10-27.

López de Lucio, Ramón. "El Gran San Blas.” In Un siglo de vivienda social, edited by Carlos Sambricio, Vol. 2, 174-176. Madrid: Nerea, 2003.

López de Lucio, Ramón. Vivienda colectiva, espacio público y ciudad. Evolución y crisis en el diseño de tejidos residenciales [Social housing, public space, city. Development and crisis of residential urban tissues] 1860-2010. Buenos Aires: Nobuco, 2013.

Lucchini, Marco. "The Quarto Cagnino District in Milan (1964-1973)." ZARCH. Journal of Interdisciplinary Studies in Architecture and Urbanism 5 (Forthcoming).

Merlin, Pierre. Les villes nouvelles en France [New Towns in France]. Paris: Puf, 1991.

Minkevičius, J. Miestai vakar, šiandien, rytoj, Vilnius, 1964; English: Cities Yesterday, Today, and Tomorrow. Vilnius: Valstybinè politinès ir mokslinès literaturos leidykla, 1964.

Mitscherlich, Alexander. Die Unwirtlichkeit unserer Städte - Anstiftung zum Unfrieden [The unreality of our cities. Incitement for strife]. Frankfurt am Main: Suhrkamp Verlag, 1965.

Monclús, Javier, Carlos Labarta, Carmen Díez, Luis Agustín, and Iñaki Bergera, eds. Paisajes urbanos residenciales en la Zaragoza contemporánea [Residential urban landscapes in contemporary Zaragoza]. Zaragoza: Prensas de la Universidad de Zaragoza, 2013.

Monclús, Javier. "International Expos and Urban Design Paradigms." In Exhibitions and the Development of Modern Planning Culture, edited by Robert Freestone and Marco Amati, 225-241. Abingdon: Ashgate, 2014.

Monclús, Javier, Carlos Labarta, and Carmen Díez, eds. Proposals for Balsas de Ebro Viejo housing estate, Zaragoza [Urban Regeneration (II). Proposals for Balsas de Ebro Viejo housing estate, Zaragoza]. Zaragoza: Prensas Universitarias de Zaragoza, 2015. 
Moneo, Rafael. Vivienda y Urbanismo en España [Housing and Urbanism in Spain]. Madrid: Banco Hipotecario, 1982.

Montaldo, V. "Quartiere Gescal di Quarto Cagnino.” L'Architettura. Cronache e Storia248, anno XXIII, giugno 1976, Roma, Mancosu, 80-85.

Moravčíková, Henrieta. "Concentrated Responses to the Issue of Prefabricated Mass Housing: Bratislava, 1950-1995." In Postwar Mass Housing East + West, Conference of Docomomo E-Proceedings 4, Scottish Centre for Conservation Studies, University of Edinburgh, Edinburgh, September 7-11, 2011, 22-29.

Mumford, Erich. "CIAM Urbanism After the Athens Charter." Planning Perspectives 7, no. 4 (1992): $391-417$.

Mumford, Erich. The CIAM Discourse on Urbanism, 1928-1960. Cambridge: MIT Press, 2000.

Orillard, Clement. "The Transnational Building of Urban Design: Interplay Between Genres of Discourse in the Anglophone World." Planning Perspectives 29, no. 2 (2014): 209-229.

Paquot, T., et al. "La Charte d'Athènes, et après?" Urbanisme 330 (2013): 35-36.

Pérez Igualada, Javier. Manzanas, bloques y casas. Formas construidas y formas de suelo en la ciudad contemporánea [Blocks, slabs and houses. Built forms and land forms in the contemporary city], 142-149. Valencia: UPV, 2005.

Pérez Andújar, Javier. Paseos con mi madre [Walks with my mother]. Barcelona: Tusquets, 2011.

Piccinato, Giorgio. L'architettura contemporanea in Francia [Contemporary architecture in France]. Rocca San Casciano: Cappelli, 1965 (La arquitectura contemporánea en Francia, Barcelona: Pomere, 1968).

Quilici, V. Ciudad rusa y ciudad soviética [Russian city and Soviet city]. Barcelona: Gustavo Gili, 1978. Ramos, M. "Evolución del tejido residencial 1936-1968 [Residential urban development 1936-1968]." In Zaragoza 1908-2008, edited by Ricardo Marco and Carlos Buil, 359-360. Zaragoza: Institución Fernando el Católico, 2009.

Reimann, Brigitte, and Hermann Henselmann. Briefwechsel [Correspondence]. Berlin: Verlag Neues Leben, 1994.

RESTATE. Restructuring Large Housing Estates in European Cities: Good Practices and New Visions for Sustainable Neighbourhoods and Cities (EU Program). Coordinator: Ronald van Kempen. Utrecht: Urban and Regional Research Centre, University of Utrecht. Last accessed December 2014. http://www.ibf.uu.se/digitalAssets/218/218528_3ra-restate.pdf.

Rossi, Aldo. L'architettura della città [The architecture of the city]. Cambridge, MA: The MIT Press, 1966. 1984.

Rowlands, R., S. Musterd, and R. van Kempen, eds. Mass Housing in Europe: Multiple Faces of Development, Change and Response. Basingstoke: Palgrave Macmillan, 2009.

Sambricio, Carlos, and Ricardo Lampreave, eds. 100 años de historia de la intervención pública en la vivienda y la ciudad [100 years history of housing and urban public intervention]. Madrid: AVS, 2008.

Sanyal, Bishwapriya, ed. Comparative Planning Cultures. Abigdon: Routledge, 2005.

Schuemer-Strucksberg, M. "Socialist Large Scale Estates in East Berlin. Instruments to Develop a Social City." La Ciudad Viva, no. 3 (2010): 27-33

Stébé, J. M. "Les grands ensembles: des cités radieuses aux zones urbaines sensibles. [Large housing estates: from radiant cities to vulnerable areas]" Univ. Stuttgart, 2011. Last accessed May 2015. http://www.unistuttgart.de/lingrom/archiv/gallerie_archiv_veranstaltungen_pdf/conference_stebe_10_11.pdf.

Strobel, R. W. "From 'Cosmopolitan Fantasies' to 'National Traditions': Socialist Realism in East Berlin.” In Urbanism. Imported or Exported?, edited by John Nasr and M. Volait,128-154. Hoboken, NJ: John Wiley, 2003.

Swenarton, M., T. Avermaete, and D. van den Heuvel, eds. Architecture and the Welfare State. New York: Routledge, 2014.

Tena, Pablo. "Universalidad y adecuación en la obra de LIGS [Universality and fitness in the work of LIGS architects]." PhD, Universidad Politécnica de Cataluña, Barcelona, 2010, 137-161.

Terán, Fernando. Historia del urbanismo en España [History of urban planning in Spain], Vol. 3, s. XIX y XX. Madrid: Cátedra, 1999. 
Thomé, P. (coord.). Créateurs d'utopies. Sarcelles. Les 50 ans du Grand Ensemble [50 years of a large scale housing estate]. Paris: Yves Michel, 2006.

Urban, Florian. Tower and Slab, Histories of Global Mass Housing. London: Routledge, 2012.

Vieillard-Baron, H. "Sur l'origine des grands ensembles." In Le Monde des Grands Ensembles, edited by Frédéric Dufaux and Annie Fourcaut, 45-62. Paris: Créaphis, 2004.

Wagenaar, Cor. Town Planning in the Netherlands Since 1800: Responses to Enlightenment Ideas and Geopolitical Realities. Rotterdam: 010 Publishers, 2011.

Wakeman, Renate. "Rethinking Postwar Planning History." Planning Perspectives 29, no. 2 (2014): $153-163$.

Waley, Paul. "From Modernist to Market Urbanism: The Transformation of New Belgrade." Planning Perspectives 26, no. 2 (2011): 209-235.

Ward, Stephen. Planning the Twentieth-Century City. Chichester: John Wiley \& Sons, 2002.

Ward, Stephen. "Soviet Communism and the British Planning Movement: Rational Learning or Utopian Imagining?" Planning Perspectives 27, no. 4 (2012): 499-524.

Wassenberg, Franz. Large Housing Estates: Ideas, Rise, Fall and Recovery: The Bijlmermeer and beyond. Delft: IOS Press, Delft University Press, 2013. 